\title{
A comparison of modelled ice thickness and volume across the entire Antarctic Peninsula region
}

\author{
Jonathan L. Carrivick ${ }^{1 *}$, Bethan J. Davies ${ }^{2}$, William H.M. James ${ }^{1}$, \\ Malcolm McMillan ${ }^{3}$, Neil F. Glasser ${ }^{4}$
}

${ }^{1}$ School of Geography and water@leeds, University of Leeds, Woodhouse Lane, Leeds, West Yorkshire, LS2 9JT, UK

${ }^{2}$ Centre for Quaternary Research, Department of Geography, Royal Holloway University of London, TW20 0EX, UK

${ }^{3}$ School of Earth and Environment, University of Leeds, Woodhouse Lane, Leeds, West Yorkshire, LS2 9JT, UK

${ }^{4}$ Department of Geography and Earth Sciences, Aberystwyth University, Wales, SY23 3DB, UK

*Correspondence to:

Dr. Jonathan Carrivick,

Email: j.l.carrivick@leeds.ac.uk

Tel.: 01133433324

\section{ABSTRACT}

Understanding Antarctic Peninsula glacier evolution requires distributed ice thickness and subglacial topography. To date, $80 \%$ of the Antarctic Peninsula mainland ice volume has only been determined at low-resolution (1 km post spacing) and the distributed ice thickness of glaciers on surrounding islands has never been quantified. In this study we applied a perfect plasticity model, selected for its simplicity, low data requirements and minimal parameterization, to estimate glacier thickness, subglacial topography and ice volume for the entire Antarctic Peninsula region. We compared the output of this simple model to that of a more sophisticated but spatially-restricted model and also to the spatially-coarse but more extensive Bedmap2 dataset. The simple model produced mean differences of $1.4 \mathrm{~m}$ (std. dev. $243 \mathrm{~m}$ ) in comparison with the more sophisticated approach for the mountainous parts of the Peninsula. It produced similar volumes for tidewater glaciers but gave unrealistic ice thickness around grounding lines. Ice thickness across low gradient plateau surfaces are mis-represented by a perfect plasticity model and thus for the southern part of the Peninsula only regional ice volume can be approximated by our model. Overall, with consideration of ice situated below sea level, model results suggest that Trinity Peninsula, Graham Land, the part of Palmer Land north of $74^{\circ} \mathrm{S}$ and all glaciers on islands contain an ice mass of $\sim 200,300 \mathrm{Gt}$, with sea level equivalent of $553 \mathrm{~mm}( \pm 11.6 \mathrm{~mm})$. Of this total $8 \%$ is from glaciers on islands, $70 \%$ of which is from Alexander Island.

\section{KEYWORDS glacier; Antarctica, sea level}


The Antarctic Peninsula has been one of the most rapidly warming areas on Earth (Morris and Vaughan, 2003; Turner et al., 2009, 2013). The effects of this warming, together with oceanic forcings, have been recognised in the dramatic collapse of multiple ice shelves (Scambos et al., 2003; Skvarca and DeAngelis, 2003; Paolo et al., 2015; Cook and Vaughan, 2010) and in widespread glacier thinning (Pritchard et al., 2009; Kunz et al., 2012), acceleration (Pritchard and Vaughan, 2007) and recession (Cook et al., 2005, 2014; Glasser et al., 2011; Ivins et al., 2011). These glacier changes are a major reason why the Antarctic Peninsula region is considered to be vulnerable to climate change (Barrand et al., 2013; Davies et al., 2014; O’Cofaigh et al., 2014; Pfeffer et al., 2014). Warming across the Antarctic Peninsula in the $21^{\text {st }}$ century has not been significant (Turner et al., 2016).

The Antarctic Peninsula ice sheet and glaciers on surrounding islands have been estimated to presently contribute between $4 \%$ and $16 \%$ of the observed global sea level rise (SLR) (c.f. Hock et al., 2009; Shepherd et al., 2012; Gardner et al., 2013). A small amount of this SLR contribution is from calving of tidewater glaciers and tabular icebergs, but also from ice shelf basal melt (e.g. Rignot et al., 2013; Depoorter et al., 2013) due to the density difference between water and ice. Snow and ice melt on the Antarctic Peninsula surface mostly refreezes within the snowpack (van Wessem, et al., 2016) and on ice shelves contributes to numerous and extensive surface ponds (Kingslake et al., 2017). Nonetheless, the importance of surface and basal melt to ice mass loss (Hock et al., 2009; Radic and Hock, 2011; Pritchard et al., 2012) is likely to persist and possibly increase in the next decades to centuries (Golledge et al., 2015). It is therefore important to estimate glacier ice thickness and bed topography across the entire Antarctic Peninsula region, for (i) baseline data useful for monitoring of these icemass changes, (ii) understanding potential local meltwater contributions via glacier hypsometry and likely equilibrium line altitude (ELA) rises, (iii) revealing subglacial topography that will become exposed as glaciers diminish, (iv) comparing ice mass loss observed from gravimetric and satellite data (e.g., Ivins et al. 2011), (v) ice flux calculations at grounding lines, and thus investigating tidewater glacier stability, e.g. due to retrograde bed slopes (Schoof, 2007) and sensitivity to ocean forcing. Furthermore, because the Antarctic Peninsula comprises several different morpho-climatic sub-regions (Barrand et al., 2013a; Cook et al., 2014), potential sea level contributions should be estimated per 69 glacier. 
Ice thickness across the entire Antarctic Peninsula region is poorly known and different methods are currently used to estimate ice thickness. Ice flow model-based approaches have the advantage of accounting for mass conservation (e.g. Morlighem et al., 2011) but can be relatively computationally expensive to run over large domains. In an approach that is not technically mass conserving due to the use of a correction procedure, Huss and Farinotti (2014) used an ice flow model driven by estimated mass balance parameters to calculate that the sea level equivalent of the Antarctic Peninsula north of $70^{\circ} \mathrm{S}$ is $69 \pm 5 \mathrm{~mm}$. However, they did not include any of the mainland glaciers between $70^{\circ} \mathrm{S}$ and $74^{\circ} \mathrm{S}$, which account for $\sim 60 \%$ of the Antarctic Peninsula region glacierised area. They also did not closely analyse the distributed ice thickness, which they posted at $100 \mathrm{~m}$ resolution, and volume on the surrounding islands even though these are amongst the most rapidly changing glaciers within the whole Antarctic Peninsula region (Davies et al., 2012). They corrected their model to ice thickness measured at points along transects flown by Operation Ice-Bridge (2016) airborne radar, but these flight lines are widely spaced and often with only one longitudinal pass per glacier. Huber et al. (2017) have completed a glacier inventory of the Antarctic Peninsula, including ice thickness and volume per glacier which they derived from Huss and Farinotti's (2014) data, but again only for part of the peninsula north of $70^{\circ} \mathrm{S}$, i.e. Graham Land.

The only complete coverage of ice thickness across the entire Antarctic Peninsula is that of the Bedmap2 dataset (Fretwell et al., 2013), which was compiled from multiple data sources and interpolated to provide a seamless though relatively coarse resolution gridded product of $1 \mathrm{~km}$. Observational ice thickness estimation methods such as Bedmap2 have the advantage that they are tuned to best-fit ice thickness and bed data, but they are highly reliant upon interpolation where data are sparse. Indeed, the $1 \mathrm{~km}$ grid of Bedmap2 does not represent the typically mountainous subglacial terrain of the Antarctic Peninsula very well (cf. Huss and Farinotti, 2014).

Therefore in this study we implement an alternative approach to ice thickness estimation which is independent of bed data and which is computationally simple and fast. Specifically, we use a perfect plasticity model to calculate subglacial bed topography and distributed ice thickness for all individual glaciers in the Antarctic Peninsula region between $60^{\circ} \mathrm{S}$ and $74^{\circ} \mathrm{S}$, including all of the mainland ice sheet and all glaciers on surrounding islands. We report our model results relative to these other (model-based and observational) methods to compare the results. 
104 The Antarctic Peninsula stretches from the northern tip of the Trinity Peninsula, including the South

105 Shetland and South Orkney islands, to glacier drainage basins in Palmer Land north of $74^{\circ} \mathrm{S}$. The entire

106 Antarctic Peninsula is $\sim 1500 \mathrm{~km}$ long and varies in width from $\sim 25 \mathrm{~km}$ wide across the Trinity

107 Peninsula to $230 \mathrm{~km}$ wide across the southern part of Graham Land and to $~ 430 \mathrm{~km}$ wide across

108 Palmer Land near the southern part of Alexander Island (Fig. 1). Between $63^{\circ} \mathrm{S}$ and $67^{\circ} \mathrm{S}$, the Peninsula

109 is characterised by a plateau with ice surface elevations up to $2000 \mathrm{~m}$. asl. Further south to $74^{\circ} \mathrm{S}$, the

110 plateau rises to $>2500$ m.asl. This topography means that the Antarctic Peninsula is subjected to

111 subpolar climates in the north and far colder conditions in the south. It is also subject to strongly

112 contrasting oceanographic and meteorological conditions across the east-west gradient (Domack et al.,

113 2006), with large amounts of snow reaching the western Peninsula as a result of the prevailing

114 Westerlies. The glaciers on the western Peninsula therefore experience high accumulation and have low

115 equilibrium line altitudes (Domack et al., 2006; Davies et al., 2012), whereas glaciers on the colder,

116 drier eastern side of the Peninsula have higher equilibrium line altitudes.

117

118 The Antarctic Peninsula is surrounded by many islands, including James Ross Island in the northeast,

119 the South Shetland Islands in the northwest, and Alexander Island in the southwest (Fig. 1). Significant

120 ice shelves include Larsen C, with an area of 50,837 $\mathrm{km}^{2}$ in 2008 , Larsen D $\left(22,602 \mathrm{~km}^{2}\right)$, George VI

$121\left(24,045 \mathrm{~km}^{2}\right)$ and Wilkins $\left(11,144 \mathrm{~km}^{2}\right)$ (Cook and Vaughan, 2010), although there are numerous

122 smaller ice shelves and floating ice tongues surrounding most of the coastline (Fig. 1). Between $63^{\circ} \mathrm{S}$

123 and $70^{\circ} \mathrm{S}$, over $96 \%$ of the mainland is ice covered (Cook et al., 2014) and between $70^{\circ} \mathrm{S}$ and $74^{\circ} \mathrm{S}$

124 virtually all of the land is ice covered.

125

126 Summer air temperatures on the Antarctic Peninsula frequently reach $>0{ }^{\circ} \mathrm{C}$, meaning that widespread

127 summer surface snowmelt occurs (Barrand et al., 2013b). The Antarctic Peninsula has warmed

128 significantly since the early 1950s with (i) warming trends on the western and northern parts;

129 Faraday/Vernadsky station $\left(65.4^{\circ} \mathrm{S}\right)$ on the western Peninsula warmed at $+0.54{ }^{\circ} \mathrm{C}$ per decade from 1951

130 to 2011 with fewer extreme cold winters, and Orcadas (South Orkney Islands) has warmed at $+0.21^{\circ} \mathrm{C}$

131 per decade since 1904 (Turner et al., 2013); and (ii) the greatest increase in positive degree days

132 experienced in the north-east at Esperanza and at Marambio (see Barrand et al., 2013). There has been a

133 climate warming hiatus in the peninsula region since the early 2000s (Turner et al. 2016; Oliva et al. 134 2017). 
135 The atmospheric warming has predominantly been attributed to a local strengthening of the circumpolar

136 westerly winds, driven by changes in the summer Southern Hemisphere Annular Mode (Martinson et al.,

137 2008; Turner et al., 2013). It has also produced an increased number of, and intensified, foehn winds,

138 which are strongly associated with surface melting across the Antarctic Peninsula ice sheet and ice

139 shelves (van den Broeke, 2005; Cape et al., 2015). Consequently ice surface melting has increased on

140 the Antarctic Peninsula since the 1950s with both longer melt seasons and more positive degree days

141 (Barrand et al., 2013b). Long-term air temperature series are strongly correlated between stations on

142 either side of the Antarctic Peninsula indicating that these trends are pervasive across Graham Land.

143 Rising air temperatures have been implicated in ice-shelf collapse (Turner et al., 2013; Cook and

144 Vaughan, 2010) and widespread glacier acceleration (Pritchard and Vaughan, 2007) and recession

145 (Davies et al., 2012). Additionally, retreat of tidewater glacier termini and glacier thinning on the western

146 side of the Antarctic Peninsula is strongly impacted by ocean warming (Martinson et al., 2008;

147 Schmidtko et al. 2014; Wouters et al. 2015; Cook et al., 2016).

\section{DATASETS AND METHODOLOGY}

149 This study applied the VOLTA model which is a perfect-plasticity approach to modelling ice thickness, 150 bed elevation and glacier volume and which is available for download via James and Carrivick (2016).

152 This model is attractive for application to multiple mountain glaciers over large spatial scales because it

153 is minimalist in its data requirements; it requires only glacier outlines and an ice surface DEM for

154 input, and because it is computationally efficient. The VOLTA model is implemented as an ArcGIS

155 (version 10.2 and more recent) tool for ease of use and all major parameters can be manually edited.

157 Whilst this type of model performs well for deriving approximations of ice thickness at land-terminating 158 mountain glaciers (James and Carrivick, 2016; Carrivick et al., 2016), and has been applied to the 159 mountain glaciers, ice caps and the major ice fields of Patagonia and southern South America (Carrivick 160 et al., 2016), it has not yet been assessed for deriving ice thicknesses across tidewater glaciers, nor for 161 glaciers flowing into an ice shelf. This is because of the inappropriateness of this type of model for both 162 calving tidewater glaciers and ice shelf tributary glaciers which are not in steady state. In particular they 163 have significant longitudinal stresses that are sensitive to (de)buttressing (e.g. Vieli and Nick, 2011), and 164 they often have rapidly-expanding flow in floating parts, for example in feeding ice shelves. Across the 165 entirety of the Antarctic Peninsula, $17 \%$ of the glaciers north of $70^{\circ} \mathrm{S}$ and $63 \%$ of the glaciers south of $16670^{\circ} \mathrm{S}$ are marine-terminating, as we have determined by identifying geospatial intersections of our 
outlines with the grounding lines mapped by Rignot et al. (2011). However, Huber et al. (2017) reported that $63 \%$ are tidewater glaciers and they based that calculation on the Landsat Image Mosaic of Antarctica (LIMA) by Bindschadler et al. (2008) and the fact that many glacier termini elevations correspond to sea level in the Cook et al. (2012) DEM. Ice shelf tributary glaciers drain 35\% of the glaciated area (Huber et al. 2017). We therefore seek to understand to what extent ice thickness across the entire Antarctic Peninsula can reasonably be estimated by using a simple perfect plasticity model and so have herein made a comparison of our ice thickness modelling results with results from other existing ice thickness models, including at grounding lines, and specifically targeting the few land-terminating and tidewater glaciers on the Antarctic Peninsula where field-measured ice thickness data are available.

Our glacier outlines combined those available for surrounding islands (Bliss et al., 2013) with glacier outlines on the Trinity Peninsula (Davies et al., 2012) and drainage basins of Graham Land (Cook et al., 2014). The outlines and drainage basins identify nunataks and thus could be masked out so that glacier area could be calculated separately from drainage basin area. The outlines were clipped so as not to extend beyond the grounding line(s) identified for all Antarctic Peninsula tidewater glaciers by Rignot et al. (2011) and so in this study we do not consider any floating ice. In total these data comprised 1781 outlines. Major glacierised regions were discriminated spatially following British Antarctic Survey (2005) name conventions for the mainland and the surrounding islands were grouped according to their geographic position relative to these mainland regions (Fig. 1, Table 1).

In this study the ice surface DEM of Cook et al. (2012) was used for regions north of $70^{\circ} \mathrm{S}$. To compute ice-surface elevation south of $70^{\circ} \mathrm{S}$ we used CryoSat-2 interferometric mode altimeter measurements. CryoSat-2 elevation data were taken from the Baseline-C distribution and spanned the period 20112014 inclusive. Using these data, we generated a continuous DEM by (i) median-gridding the data at 5 $\mathrm{km}$ resolution, (ii) removing noisy or topographically-complex cells where the median absolute deviation of measurements exceeded $50 \mathrm{~m}$, and then (iii) posting to a $100 \mathrm{~m}$ grid using bilinear interpolation. Ice surface DEMs were projected into a Cartesian coordinate system and clipped to the spatial extent of the glacier outlines for efficiency when running the model. We compared our centreline point ice thickness values to the ice thickness points of Operation Ice-Bridge (2016): data

194 from http://nsidc.org/icebridge/portal/, and we compared our gridded ice thickness with the gridded 195 data in the Bedmap2 dataset of Fretwell et al. (2013), and with that of Huss and Farinotti (2014). While Bedmap2 is provided at a nominal $1 \mathrm{~km}$ resolution, the actual resolution for the peninsula region is much coarser. Huss and Faronotti's dataset is at $100 \mathrm{~m}$ resolution. 


\section{Glacier centrelines}

200 Identification of glacier ice surface flow trajectories requires fully distributed velocity fields, which are available for Antarctica on a $300 \mathrm{~m}$ grid from Rignot et al. (2011). Using these flow trajectories as a guide, because they only provide $\sim 70 \%$ coverage over the Antarctic Peninsula region, we manually digitized glacier centrelines from the middle of each glacier terminus up-glacier and approximately midway between and parallel to the lateral margins of any glacier ablation tongue, and thence towards any prominent saddles or cols on cirque headwalls or on ice divides. Where ice divides were ambiguous we inverted the DEM and then ran a hydrological routing function in ArcGIS 10.4, which is normally used to delineate valley floor flow paths but in this case identified 'ridge lines'. The exact position of our centrelines, especially south of $70^{\circ} \mathrm{S}$ is thus partly a function of the quality of the DEM. We used the ridgeline analysis only as a guide and we performed a sensitivity test on the number and position of centrelines as will be shown below.

212 As described by James and Carrivick (2016), a single centreline may not be suitable if a glacier is of complex geometry due to multiple tributaries or cirques. Whilst the lack of a secondary tributary centreline is the main issue, the initial centreline is also laterally deflected where the perpendicular traverses are elongated as they continue into the secondary tributary. To overcome these issues, an upstream area approach was used to delineate separate tributaries. Iteratively working down the initial centreline, upstream area is calculated. Total area steadily increased down-centreline, but a marked (rate of) increase occurs when a new tributary enters. VOLTA calculates area at an interval equal to 1 $\%$ of centreline length with a new tributary identified if area increases by $>30 \%$ between successive points. Furthermore, we stipulate for computational efficiency that any new tributary must also have an area of at least $20 \%$ of the total for any glacier.

\section{Calculating ice thickness at points along the centreline}

224 Ice thickness $h$ of mountain glaciers can be estimated from a glacier surface slope by:

$$
h=\frac{\tau_{b}}{f p g \tan \alpha}
$$

where, $\tau_{b}$ is basal shear stress, a shape factor $f$ is required to account for valley sides supporting part of the weight of the glacier, $\rho$ is ice density, $g$ is the gravitational constant and $\alpha$ is the surface slope angle. Since the VOLTA model is published (James and Carrivick, 2016) we simply cover the most salient 
231 points here. These points firstly concern the basic operation of the model, and secondly the question of 232 how to recognize the uncertainty introduced by using this sort of model on Antarctic Peninsula glaciers. 233 The Peninsula includes tidewater glaciers and wide lobate outlet type glaciers and thus these glaciers 234 can have a completely different morphology (due to different processes) to land-terminating mountain 235 glaciers.

237 Basal shear stress, $\tau_{b}$, is variable between individual glaciers due mainly to basal water pressure, ice 238 viscosity and subglacial sediment deformation. For ice thickness estimations such as those within in 239 this study, $\tau_{b}$ does not have to be varied longitudinally for an individual glacier as a constant value can 240 reproduce accurate thickness estimates along the length of a centreline (Li et al., 2012). Previous 241 studies have used an empirical relationship between altitudinal extent and $\tau_{b}$ that was developed by 242 Haeberli and Hoelzle (1995) but the relationship is weak $\left(\mathrm{r}^{2}=0.44\right)$ and Linsbauer et al. (2012) 243 reckoned an uncertainty of up to $\pm 45 \%$ using this method. Therefore in this study we employ a 244 relationship established by Driedger and Kennard (1986a), using area and slope in an elevation band 245 approach:

$$
\tau_{b}=2.7 \cdot 10^{4} \sum_{i=1}^{n}\left(\frac{A_{i}}{\cos \alpha_{i}}\right)^{0.106}
$$

where the elevation band area $\left(A_{i}\right)$ is in $\mathrm{m}^{2}$ and $\tau_{b}$ is in $\mathrm{Pa}$. This method was tested by Driedger and Kennard (1986b) as part of a volume estimation study and they found a standard deviation of error of 5 $\%$ when comparing modelled with measured volumes. We calculated $A_{i}$ and $\cos \alpha_{i}$ over $200 \mathrm{~m}$ icesurface elevation bands to produce glacier specific average $\tau_{b}$ values that were consequently applied to each centreline point.

We calculated $h$ at points spaced $100 \mathrm{~m}$ apart on all centrelines where that spacing was selected partly with respect to our $100 \mathrm{~m}$ posting to combine the ice surface DEMs and partly due to the spatial coverage of this study and a desire to maintain computational efficiency. Whilst $f$ has been incorporated as a constant (usually 0.8 cf. Nye et al., 1965; e.g. Linsbauer et al., 2012), we adopted the practice of Li et al. (2012) who developed a more physically realistic method to dynamically adjust $f$ depending on the local width of a glacier. In detail, Li et al. (2012) estimated ice thickness perpendicular to the ice surface but in this study we are dealing with GIS-analysed glacier geometry so to consider 'vertical' ice thickness, h, i.e. that perpendicular to a horizontal x-axis we re-write the Li et al. (2012) equation as: 


$$
h=\frac{0.9 w\left(\frac{\tau_{B}}{p g \tan \alpha}\right)}{0.9 w-\left(\frac{\tau_{B}}{p g \tan \alpha}\right)}
$$

where $w$ is half the glacier width at the specified point on a centreline.

We then implemented an automatic check for erroneous $h$ values in the vicinity of nunataks and tributary confluences (cf. Li et al. 2012) by: (i) checking if the perpendicular 'width' line intersected another centreline and (ii) cross checking if the resulting $f$ value (Eq. 1$)$ is realistic (>0.445, equal to a half width to centreline thickness ratio of 1: cf. Nye, 1965). At points where either of these conditions were met, $h$ was calculated using Eq. 1, with $f$ set to that of the average of all points on the same tributary.

Ice thickness, $h$, will tend to infinity as surface slope tends to zero, meaning $h$ may be overestimated in regions of flatter ice surface (Li et al., 2012; Farinotti et al., 2009). In this study a 'minimum slope threshold' $\alpha_{0}$ of $1.5^{\circ}$ was used to re-assign any lower slope values to that minimum value. We note that Farinotti et al. (2009) used $5^{\circ}$ and $\mathrm{Li}$ et al. (2012) used $4^{\circ}$, but since $49 \%$ of the ice surface across the Antarctic Peninsula (5\% of area outside Palmer Land; $95 \%$ of area within Palmer Land) is $2^{\circ}$ or less this was too high for application to the glaciers of the Antarctic Peninsula. Additionally, the 'low slope' parts of ice surfaces are situated either within the trunks of the major outlet glaciers outside of Palmer Land, or across the southern Antarctic Peninsula plateau of Palmer Land. Approx. $47 \%$ of the ice surface in this study is $<1.5^{\circ}$.

\section{Interpolating distributed ice thickness and bed topography}

284 Distributed ice thickness was interpolated from the centreline points across each glacier using the ANUDEM 5.3 interpolation routine (Hutchinson et al., 1989). ANUDEM generates preferably concave shaped landforms, thus mimicking the typical parabolic shape of (idealised) glacier beds (Linsbauer et al., 2012). It is commonly applied to estimating bed topography of both mountain valley glaciers (Farinotti et al., 2009; Linsbauer et al., 2012; Li et al., 2012; Fischer and Kuhn, 2013), to ice caps and ice fields (Carrivick et al., 2016) and to ice sheets, such as within the Antarctica Bedmap2 dataset (Fretwell et al., 2013). Interpolations of ice thickness through ice divides was achieved simply by 'dissolving' (i.e. removing) those parts of glacier outlines that were in contact with each other. If glaciers were exceptionally wide, such as in the southern part of the Peninsula, we digitized multiple 
sub-parallel centrelines within a single glacier outline and this served to accommodate applying the VOLTA model to large low-gradient lobate and coalescing outlet glaciers that are typical of the southern part of the Antarctic Peninsula (Fig. 2).

Once thickness $h$ for each grid cell in each glacier had been interpolated, total volume $V$ was calculated:

$$
V=\sum\left(c^{2} h\right)
$$

where $c$ is the grid cell size.

\section{Uncertainty estimates}

James and Carrivick (2016) compared modelled glacier volume to that derived from field measurements of (individual) (land-terminating) valley glaciers around the world, and found worst-case $26.5 \%$ underestimates and $16.6 \%$ overestimates. Median deviations of modelled to measured ice thickness on a cell by cell basis were $~ 10 \%$ (James and Carrivick, 2016 their Fig. 9 and their Table 2). For comparison, uncertainties for volume-scaling approaches range from $30 \%$ for large samples to 40 \% when considering smaller ( 200) samples Farinotti and Huss, 2013; Bahr et al., 2014a, b). In this study, model error comes from individual model parameters, from the perfect plasticity assumption and uncertainty comes from the spatial interpolation from centreline thicknesses to glacier-wide thickness. James and Carrivick (2016) compared centreline modelled ice thickness with ice thickness from field radar measurements on alpine glaciers around the world and found differences $<11 \%$. They also found that the modelled volume of large glaciers was least sensitive to model parameters basal shear stress, slope averaging distance, minimum slope threshold and effective width slope threshold, in comparison to the sensitivity of small glaciers to these parameters Across the entire Antarctic Peninsula mainland and surrounding islands $82 \%$ of all glaciers are $>2 \mathrm{~km}^{2}$ (and $63 \%$ are $>5 \mathrm{~km}^{2}$ ) so at least in regard of their size should be well-suited to application of this model.

In this study we firstly compared our ice thickness results to independent ground penetrating radar (GPR) measurements made by Engel et al. (2012) on IJR-45 (a land-terminating valley glacier) and across the Davies Dome ice cap, both on the Ulu Peninsula of James Ross Island. Our uncertainty analysis was informed by the work on mountain glaciers of James and Carrivick (2016), but also took advantage of the aforementioned GPR data, which is not included in Bedmap2. Modelled-measured comparisons were made along glacier centrelines and on flow-perpendicular transects where GPR- 
measurements have been made and produced median modelled-measured differences of $32 \mathrm{~m}$ and a maximum of $62 \mathrm{~m}$ (Fig. 3). On the basis of these comparisons we herein report modelled ice thickness on land-terminating valley glaciers with uncertainty of $\pm 31 \%$ and glacier volume with uncertainty of \pm $20 \%$ but note that these uncertainties are both worst case estimates. For land-terminating ice caps the uncertainty in ice thickness is up to $45 \%$ (Fig. 3) due to the shallow gradient ice surfaces but ice volume uncertainty is the same at $20 \%$ because over- and under-estimates of ice thickness tend to cancel each other out.

Secondly, to gain an estimate of the uncertainty in our model for the distributed ice thickness in the vicinity of grounding lines, we compared our ice thickness results with those of Farinotti et al. (2013) for Flask Glacier, and with those of Farinotti et al., (2014) for Starbuck Glacier. Both datasets were incorporated by Huss and Farinotti (2014) in their study to correct their model. These comparisons of model results (Fig. 4) show that our model has considerable error in the vicinity of a grounding line, because it tends towards zero ice thickness at non-adjacent glacier boundaries as would be the case for land-terminating glaciers. However, that effect does not propagate more than a few kilometres upglacier and so has only a spatially-restricted effect on distributed ice thickness, and a negligible effect

It is apparent that for the glaciers on the Antarctic Peninsula bounded by steeply sided mountain slopes and thus of an alpine character, our model can replicate the ice thickness suggested by Huss and Farinotti, as evidenced by the general spatial pattern of ice thickness and by a histogram of absolute differences between the two models where the mean difference is $1.4 \mathrm{~m}$, the standard deviation of the differences 676 and $-953 \mathrm{~m}$, respectively (Fig. 4). On the basis of these comparisons of our modelled ice thickness for tidewater glaciers with that measured, we herein report modelled ice thickness across tidewater glaciers with a mean uncertainty of $\pm 16 \%$ and glacier volume with a mean uncertainty of \pm $20 \%$. We assume that these uncertainty estimates are representative of the surrounding islands, the Trinity Peninsula and for Graham Land due to the similar mountain topography in those regions.

Thirdly, we considered the utility of our model across Palmer Land, where interpolation distances (glacier widths) are much larger, where ice surface slopes are very low and where the only independent ice thickness measurements available are those of Operation Ice-Bridge. Manually moving (laterally) our 
thickness or on individual glacier volume. However, changing the number of sub-parallel centerlines did have a significant effect and for this reason we located sub-parallel centrelines (Fig. 2A) where thicker parts of the glaciers as depicted in the Bedmap2 dataset reached the grounding line (Fig. 2B). Our results reported below include a cross-over analysis of our centreline ice thickness points with ice thickness points derived from airborne radar surveys.

\section{Spatial and statistical analysis}

364

Zonal statistics per glacier, per major glacial region and per major glacier catchment were extracted from ice-surface elevation, ice thickness and subglacial bed topography grids. Areas with bed elevations below sea level were automatically extracted via a binary reclassification of bed topography [ $>0 \mathrm{~m} \cdot \mathrm{asl}=0 ;<0 \mathrm{~m} \cdot \mathrm{asl}=1$ ], conversion of the ' 1 ' values in this grid to polygons, and then zonal analysis of bed topography per polygon zone. The part of ice below sea level in each grid cell column was excluded from estimates of potential sea level rise. Overdeepenings were automatically extracted from bed topography by 'filling sinks' in the bed topography and analysed in the same manner as for bed elevations.

\section{Conversion of ice thickness to potential sea level rise}

As snowfall and temperature are not uniform across the Peninsula, the thickness of the snow and firn layer is not uniform and therefore gridded 'ice column' densities are spatially variable. However, quantifying this spatial variation is not trivial and is poorly constrained by field observations. We therefore converted our ice volumes to a mass by assuming a mean density of $852 \mathrm{~kg} . \mathrm{m}^{-3}$ to account for the fact that each grid cell is not just a thickness of ice but also with some significant depth of snow and a firn layer. The firn layer is especially prominent in Palmer Land (Huss, 2013; van Wessem, 2016), according to the modelling by Ligtenberg et al. (2011) using a firn densification model that included liquid water processes (meltwater percolation, retention and refreezing), that was tuned to fit depthdensity observations, and that was driven by RACMO at $5.5 \mathrm{~km}$ resolution. This mean density is the same value as used by Huss and Farinotti (2014) for the mountainous northern part of the Antarctica Peninsula. Lower density firn layers are thickest on high dry plateau (Ligtenberg et al;.., 2011) but it is also in those places, especially Palmer Land, that overall ice thickness is greatest and so mean (ice column) density is probably not to dissimilar to the single global value we use. The mass of ice was converted to a sea level equivalent (SLE) using an ocean area of $3.618 \times 10^{8} \mathrm{~km}^{2}$. Our SLE calculations are not very sensitive to the choice of density value; changing the mean density from 852 to $900 \mathrm{~kg} \cdot \mathrm{m}^{-3}$ with a volume of 100,000 $\mathrm{km}^{2}$ produces an increase in SLE of $13 \mathrm{~mm}$. 


\section{RESULTS}

392 Our modelled ice thickness grid cell values fall into two groups; those computed on glacier centrelines 393 using the perfect plasticity assumption, and those interpolated between the centrelines and the glacier perimeter. A cross-over analysis of our modelled ice thickness points on our centrelines and the closest Operation Ice-Bridge (OIB) (2016) airborne radar ice thickness points (if within $500 \mathrm{~m}$ ) gives an $\mathrm{r}^{2}$ value of 0.41 (Fig. 5A). This is better than the correlation between our ice thickness points and Bedmap2 ice thickness values $\left(r^{2}=0.38\right.$; Fig. $\left.5 B\right)$. But, it is important to realise that (i) Bedmap2 was generated by interpolating from the OIB (2016) points, although the interpolation routine did not preserve the original thickness values, and (ii) Huss and Farinotti (2014) adjusted their model to best-fit the OIB point ice thickness values. It is therefore promising that whilst our model centreline point ice thickness values have a weak agreement with Bedmap2 ice thickness grid values $\left(r^{2}=0.38\right.$ : Fig. 5B $)$, there is a moderately high correlation between our model centreline point ice thicknesses and the corresponding grid cell values of ice thickness by Huss and Farinotti (2014) $\left(r^{2}=0.58\right.$ : Fig. 5C).

Unfortunately, the applicability of our model across Palmer Land is very limited due to the extensive shallow gradient ice surface slopes. Our examination of 'cross overs' of our centreline ice thickness estimates with OIB ice thickness points on a very big and very low gradient glacier in Palmer Land shows 408 that 'minimum slope threshold' $\alpha_{0}$ below $1.5^{\circ}$ (a value of 4 is typically for mountain glacier applications of perfect plasticity models) are necessary to obtain any ice thickness estimate at all, and even that estimate is unrealistic with over- and under-estimates (relative to Bedmap2) > $100 \%$ possible (Fig. 6).

411 The spatial pattern of the difference in our modelled ice thickness with that of the nearest (if within 500 m) OIB point ice thickness is mapped in Figure 7 and this pattern is dominated by greater differences south of $70^{\circ} \mathrm{S}$, illustrating the effects of (i) a poorer ability to compare our modelled ice thickness on centreline points with OIB points due to much larger glaciers with more sparse centrelines (and more sparse OIB lines) and thus with greater distances from a centreline to an OIB point, (ii) more realistic ata-point ice thickness estimates in steeper mountainous topography (James and Carrivick, 2016) than over broad low-relief ice sheet plateau areas (Figure 7; e.g. Carrivick et al., 2016). Farinotti (2014) is similar (Fig. 8A), but some important discrepancies in the ice thickness modelled in 
and Farinotti (2014) and resolves the same subglacial mountainous topography (inset of Fig. 8A).

422 However, our ice thickness is apparently too great along the interior of the northern Antarctic Peninsula 423 (Fig. 8A, B, C). In the region south of $70^{\circ} \mathrm{S}$ and on the surrounding islands our modelled pattern of ice 424 thickness generally agrees with that of Bedmap2 (Fig. 8A; Table 2), but appears smoother primarily 425 due to the different DEMs used to derive the Bedmap2 model and our model.

The most notable discrepancies in the models are thicker ice modelled in this study on Adelaide Island and on Alexander Island than in Bedmap2, and thicker ice modelled in this study in the southern part of Graham Land than in Bedmap2 or in Huss and Farinotti (2014) (Fig. 8A; Table 2). In western Palmer Land our model estimates ice thickness that is up to several times that of Bedmap2, which is disconcerting given that Bedmap2 was fitted to OIB data. The effect of manually drawn multiple subparallel centrelines is regrettably evident in the ice thickness grid across Palmer Land (Fig. 2). We therefore contend that whilst our model is unsuitable for estimating distributed ice thickness across the extensive shallow gradient glaciers of Palmer Land, with caution estimates of regional ice volume can be made.

The results of this study and the model of Huss and Farinotti both suggest thicker ice in the mountainous subglacial troughs than the Bedmap2 dataset indicates. In some instances these differences are large; up to $\pm 1000 \mathrm{~m}$ (Fig. 8B, Fig. 5). However, Table 2 shows that when region-byregion statistics are calculated the relative over- or under-estimation by any of the three models varies between major regions. Our predicted ice thicknesses across Palmer Land have a spatial pattern that agrees with Bedmap2 across the eastern side than the western side of the Peninsula (Fig. 8B). Overall, the ice thickness modelled in this study tends to be over-estimated compared to Bedmap2 (Fig. 9A), and tends to be lower than modelled by Huss and Farinotti (2014) (Fig. 9B). The ice thickness of Huss and Farinotti tends to be thicker than in Bedmap2 (Fig. 9C). If spatial pattern (Fig. 8) and grid cell values (Fig. 9) are compared then our modelled ice thickness has greater agreement with the modelled ice thickness of Huss and Farinotti (2014) than with those of Bedmap2. That general agreement is remarkable given the number ('count' in Fig. 9) of grid cells being compared between our study and that of Huss and Farinotti. Our modelled subglacial topography below sea level has a spatial pattern very similar to that of Huss and Farinotti (2014) but that pattern compares less well with the Bedmap2 (Fretwell et al., 2013) dataset (Fig. 10). The parts of glaciers below sea level in red in Figure 10 will 450 have an impact on sea level because of the density difference between ice and water and so if (all) that 451 ice were removed and would raise sea level (by a maximum of) $~ 14 \mathrm{~mm}$. 
452 Our results indicate an ice volume on the mainland Antarctic Peninsula that is typically twice that per 453 major region than that provided by Bedmap2, except for 'PL-west' where our model suggests a similar 454 total ice volume reported in Bedmap2, and 'PL-east' where our modelled ice volume is a $20 \%$ under455 estimate in comparison with Bedmap2. On surrounding islands our modelled ice volume is on average $45650 \%$ more than Bedmap2. There is great discrepancy between our modelled ice volume below sea 457 level with that of Bedmap2 with the greatest proportional differences in the region 'TP-east' (Table 3).

458 For mainland regions with comparable coverage; namely TP-west, TP-east, GL-west and GL-east, our 459 modelled volumes are 1.5 times more than those by Huss and Farinotti (Table 3). For surrounding 460 islands our modelled volume(s) are comparable to Huss and Farinotti's (2014) results for most regions 461 but 'C-west' is very different (Table 3) due to a more limited spatial coverage in their study. For zones 462 with complete coverage, our volume(s) below sea level are typically three times that modelled by Huss 463 and Farinotti for mainland regions and four times that for surrounding island regions (Table 3).

464 These discrepancies in spatial coverage, spatial resolution and method between the three models result 465 in estimates of sea level equivalent (SLE) ranging from $35 \mathrm{~mm}$ to $715 \mathrm{~mm}$ for the Antarctic Peninsula 466 mainland, and from $6 \mathrm{~mm}$ to $55 \mathrm{~mm}$ for the surrounding islands (Table 3). The estimated SLE 467 calculated by our simple model is $71 \%$ and $84 \%$ for the mainland and for the surrounding island 468 regions, respectively, of that suggested by the Bedmap2 data. Our estimates of SLE agree well with 469 those of Huss and Farinotti (2014) on a region-by-region basis, the biggest difference being $30 \%$ (27 470 mm versus $19 \mathrm{~mm}$ ) for region GL-east (Table 3).

471 The spatial pattern of SLE per major region determined in this study emphasises the importance of 472 including Palmer Land and Alexander Island (Fig. 11A) in SLE estimates. Were they to melt entirely, 473 Trinity Peninsula could contribute $4 \mathrm{~mm} \pm 0.8 \mathrm{~mm}$, Graham Land $44 \mathrm{~mm} \pm 8.8 \mathrm{~mm}$, and Palmer Land $474459 \mathrm{~mm} \pm 91.8 \mathrm{~mm}$ to sea level, due to ice masses of $1569 \mathrm{Gt}, 16,038 \mathrm{Gt}$ and 166,263 Gt, respectively 475 (Table 3). Alexander Island accounts for $32 \mathrm{~mm} \pm 6.4 \mathrm{~mm}$ SLE, which is $70 \%$ of that from all 476 surrounding islands (Table 3). On a glacier-by-glacier basis, the spatial pattern of potential SLE is 477 similar to that within the region-by-region pattern but indicates heterogeneity (i) across Graham Land 478 and across Alexander Island where in both cases the northern part has higher potential contributions 479 than the southern part (Fig. 11B), and (ii) across Palmer Land where glaciers draining eastwards tend to 480 have lower SLE than those draining westwards (Fig. 11B). 
483 Our modelled ice thickness has the same $100 \mathrm{~m}$ spatial sampling as the model of Huss and Farinotti 484 (2014) and resolves the same sort of rugged subglacial topography which is less well represented in the $4851 \mathrm{~km}$ grid posting of Bedmap2 (Fretwell et al., 2013). Furthermore, our modelled ice thickness is more 486 similar in planform distribution (Fig. 8) and in magnitude to that of Huss and Farinotti than to that of 487 Bedmap2 (Figs. 5, 6, 7), which is remarkable given the far more sophisticated nature of the Huss and 488 Farinotti (2014) model, and given the basis of Bedmap2 being OIB (2016) data. The discrepancy in 489 magnitude of local (per grid cell) modelled ice thickness between this study, Bedmap2 (Fretwell et al., 490 2013) and Huss and Farinotti (2014) of up to $1000 \mathrm{~m}$ in some extreme cases (Fig. 9) contrasts with the 491 generally good agreement in spatial pattern (Fig. 8). Thus whilst there is uncertainty in modelled ice 492 thickness at any point, considerably so across Palmer Land, this uncertainty is apparently reduced by 493 spatial averaging; specifically by consideration of glacier (catchment) volumes in preference to 494 absolute ice thickness. Therefore with caution our model estimates of ice volume across Palmer Land 495 496 can be combined with our estimates of ice volume for the northern parts of the Antarctic Peninsula and surrounding islands to give the first complete coverage assessment of ice volume and SLE contributions. Our use of the most recent distribution of CryoSat-2 data for parts of the Antarctic Peninsula mainland south of $70^{\circ} \mathrm{S}$ has improved our knowledge of ice thickness, bed topography and SLE in that part of the Antarctic Peninsula.

Our discrimination of ice volume per major region quantifies the (i) dominance of western Palmer 502 Land, which we propose contains $47 \%$ of the total mainland ice volume (Table 3 ) and which is in agreement with the findings of Schannwell et al. (2018), (ii) importance of Alexander Island, which contains $70 \%$ of the total ice volume on surrounding islands, and (iii) importance of the surrounding islands, which contain $12 \%$ of all ice across the Antarctic Peninsula (Table 3). These quantifications are important because 'mountain glacier and ice cap' type glaciers have been highlighted as being especially vulnerable to climate change because they are relatively small and have relatively fast response times (Raper and Braithwaite, 2006; Meier et al., 2007). Furthermore glaciers on surrounding islands of the Antarctic Peninsula are situated at a lower elevation than those on the mainland and so are more susceptible not only to warming oceans (Meredith et al., 2005; Martinson et al., 2008; Schmidtko et al., 2014; Wouters et al., 2015; Cook et al. (2016) because the majority are tidewater glaciers (Davies et al., 2012), but also to warming air temperatures (Turner et al., 2012). Since $24 \%$ of the mainland glaciers and $47 \%$ of the surrounding island glaciers are below sea level (Table 3 ) they are 
514 especially vulnerable to ice-shelf collapse in situations where they flow over retrograde slopes into ice 515 shelves (Scambos et al., 2003, 2014; Glasser et al., 2011; Rott et al., 2011).

516 The mountain glaciers on the surrounding islands have a total of 16,472 Gt ice mass with the capacity 517 to contribute $8 \%$ of SLE from the Antarctic Peninsula, which is higher than $5 \%$ suggested by the 518 Bedmap2 data (Table 3). The context of these figures is that previously it has been suggested that 519 mountain glaciers surrounding the Antarctic Peninsula account for $25 \%$ of the total sea level rise 520 potential from glaciers and icecaps worldwide excluding the mainland Greenland and Antarctic 521 mainland ice sheet (Radic and Hock, 2010; Radic and Hock, 2011). For comparison, Pritchard and 522 Vaughan (2007) examined the northern Antarctic Peninsula between $64^{\circ} \mathrm{S}$ to $70^{\circ} \mathrm{S}$ and suggested a 523 total SLE of $242 \mathrm{~mm}$, which given that geographical extent excludes most of Palmer Land seems an 524 over-estimate given the $508 \mathrm{~mm}( \pm 101 \mathrm{~mm})$ determined by this study for the whole mainland (Table 525 3). Bamber et al. (2009) also suggested that the Antarctic Peninsula has a SLE of $240 \mathrm{~mm}$. For these 526 studies it is unclear exactly which glacier catchments were included and how these sea-level rise 527 figures were derived. Drewry (1983) and Heroy and Anderson (2005) suggested that the Antarctic 528 Peninsula and surrounding glaciers contain a SLE of $300 \mathrm{~mm}$ to $400 \mathrm{~mm}$..

530 Our new estimates of the present ice volume, ice mass and SLE of the Antarctic Peninsula provide 531 context to contemporary observations of ice loss. Ivins et al. (2011) reported ice mass loss for the 532 northern Antarctic Peninsula (i.e. Graham Land) of $41.5 \pm 9 \mathrm{Gt} \mathrm{yr}^{-1}$ between 2003 and 2009. For the 533 same time period, Gardner et al. (2013) reported ice mass loss for glaciers peripheral to the peninsula 534 and for islands surrounding the peninsula of 6 and $7 \pm 4 \mathrm{Gt} \mathrm{yr}^{-1}$, respectively. Considering the entirety

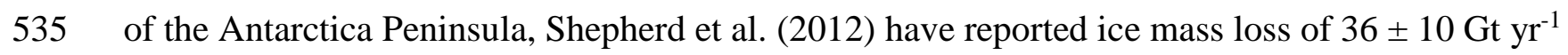
536 between 2005 and 2010. Rates of ice volume and ice mass change primarily between years 2003 and 5372008 were reported by Scambos et al. (2014) of $27.7 \pm 8.6 \mathrm{~km}^{3} \mathrm{a}^{-1}$ and $24.9 \pm 7.8 \mathrm{Gt} \mathrm{a}^{-1}$, equal to -0.73 $538 \mathrm{~m} \mathrm{a}^{-1}$ w.e. Sasgen et al., (2013) reported that the northern Antarctic Peninsula had mass loss $-26 \pm 3 \mathrm{Gt}$ $539 \mathrm{yr}^{-1}$ between 2003 and 2012. There is an obvious need for more field data to constrain both directly540 measured ice thickness, such as from ground penetrating radar and seismics, and also indirectly 541 estimated ice thickness changes (e.g. Carrivick et al., 2012). Notwithstanding the outstanding coverage 542 of the OIB data (2016) across the Antarctic Peninsula, directly measured distributed bed topography is 543 known from only a few small glaciers on James Ross Island (Engel et al., 2012; Fig. 3), and from Flask 544 Glacier and Starbuck Glacier on the Antarctic Peninsula mainland (Farinotti et al., 2013, 2014; Fig. 4). 545 Therefore the close analysis of ice thickness and volume on the surrounding islands that we have 
provided is novel and of great utility for all concerned with present day glaciers and ongoing glacier changes. The circumstances for which this study's gridded ice thickness data across the mainland Antarctic Peninsula could most beneficially be used in partitioning volume, mass and melt water equivalent contributions under scenarios of changes in climate and oceanic forcing on the glacier systems.

\section{CONCLUSIONS}

553 We have modelled high-resolution (100 m grid) subglacial bed topography and distributed ice 554 thickness across a far greater spatial extent than previously considered. We achieved this in a far 555 simpler manner than previous efforts, requiring less input data and less parameterization. We have used the most-recent and best available DEMs. This approach has advantages, such as speed and coverage, and disadvantages, such as high uncertainty in at-a-point thickness. Specifically, we discriminate all glaciers of the mainland Antarctic Peninsula north of $74^{\circ} \mathrm{S}$ and all glaciers on surrounding islands. We have reported ice thickness and bed elevation statistics, glacier volume and potential sea-level rise for each major mainland region and surrounding island group. It is important to make spatially-distributed discriminations because the Antarctic Peninsula spans several morpho-climatic zones.

563 Our comparison of model results highlights discrepancies between our modelled ice thickness, that of Bedmap2 (Fretwell et al., 2013) and that of Huss and Farinotti (2014). Our model is apparently able to reproduce the salient features of the rugged subglacial topography of the northern part of the Antarctic Peninsula (Trinity Peninsula, Graham Land and the surrounding islands) as well as total ice volume. In this study we have shown that if an emphasis is maintained on ice volume, and on ice thickness statistics per glacier rather than absolute ice thickness at-a-point, then a perfect plasticity type of model can be applied with caution to marine-terminating as well as land-terminating glaciers. Our ice thicknesses can be considered only as a first order estimate.

572 Our modelled ice thickness compares less favourably with that from previous efforts across Palmer 573 Land. This is undoubtedly due to its poor treatment of very low gradient ice surfaces, but also perhaps a 574 product of the newer CryoSat DEM that we have used for that region which is smoother than ASTER 575 GDEM, for example. Recognizing that our model probably over-estimates ice thickness and hence 576 volume, though not as much as Bedmap2, we suggest that western Palmer Land contains $41 \%$ of the total ice volume of the Antarctic Peninsula. We have quantified that glaciers on surrounding islands 
600

601

602

603

604 605

606 607

contain $12 \%$ of all ice across the Antarctic Peninsula and of this Alexander Island contains $70 \%$.

There are greater potential SLE contributions from glaciers on the eastern side of Graham Land than on the west and vice versa for Palmer Land. This asymmetry in SLE is interesting for considering atmospheric versus oceanic impacts on the Antarctic Peninsula glaciers.

The total ice mass on the Antarctic Peninsula is estimated to be $200,343 \mathrm{Gt}$, a SLE of $553 \mathrm{~mm}( \pm 110.6$ $\mathrm{mm}$ ), of which $8 \%$ is contributed from glaciers on surrounding islands. Trinity Peninsula could contribute $4 \mathrm{~mm} \pm 0.8 \mathrm{~mm}$, Graham Land $44 \mathrm{~mm} \pm 8.8 \mathrm{~mm}$, and Palmer Land $459 \mathrm{~mm} \pm 91.8 \mathrm{~mm}$ to sea level (Table 3). Across the entire Antarctic Peninsula, $24 \%$ of the mainland ice and $47 \%$ of ice on surrounding islands is below sea level, making these glaciers, especially those on Alexander Island and in western Palmer Land, extremely vulnerable to climate change as manifest in rising air and ocean temperatures.

Future development of the simple approach to estimating ice thickness and volume presented herein obviously needs to accommodate extensive shallow gradient ice surfaces. Other improvements could focus firstly on derivation of glacier flow lines using longitudinal flow stripes and lineations (e.g. Ely and Clark, 2016) rather than relying on relatively sparse centrelines. A representation of floating glacier terminii Could be made via a flotation criteria implemented at or close to the grounding line perhaps by using measured (or from the plastic model) elevation estimates to get a height above sea level and by assuming that ice thickness is equivalent to the thickness of the water column after accounting for density differences. A plastic model which does something similar, though in this case the ice surface is unknown, is in Gowan et al (2016).

\section{REFERENCES}

Bahr, D. B., Pfeffer, W. T. \& Kaser, G. Glacier volume estimation as an ill-posed inversion. Journal of Glaciology 60, 922-934 (2014a).

Bahr, D. B., Pfeffer, W. T., \& Kaser, G. A Review of Volume-Area Scaling of Glaciers. Reviews of Geophysics 53, 95-140 (2014b).

Bamber, J. L., Riva, R. E. M., Vermeersen, B. L. A. \& Le Brocq, A. M., Reassessment of the potential sea-level rise from a collapse of the West Antarctic Ice Sheet. Science 324, 901-903 (2009).

Barrand, N.E., Hindmarsh, R.C., Arthern, R.J., Williams, C.R., Mouginot, J., Scheuchl, B., Rignot, E., Ligtenberg, S.R., Van Den Broeke, M.R., Edwards, T.L. \& Cook, A.J. Computing the volume response of the Antarctic Peninsula ice sheet to warming scenarios to 2200. Journal of Glaciology 59, 397-409 (2013a). 
612 Barrand, N.E., Vaughan, D.G., Steiner, N., Tedesco, M., Munneke, P.K., Van den Broeke, M.R. \& 613 Hosking, J.S. Trends in Antarctic Peninsula surface melting conditions from observations and regional 614 climate modeling. Journal of Geophysical Research: Earth Surface 118, 315-330 (2013b).

615 Bindschadler, R., Choi, H., Wichlacz, A., Bingham, R., Bohlander, J., Brunt, K., Corr, H., Drews, R., 616 Fricker, H., Hall, M. \& Hindmarsh, R., 2011. Getting around Antarctica: new high-resolution mappings 617 of the grounded and freely-floating boundaries of the Antarctic ice sheet created for the International 618 Polar Year. The Cryosphere 5, 569-588.

619 Bliss, A. K., Hock, R., \& Cogley, J.G. A new inventory of mountain glaciers and ice caps for the 620 Antarctic periphery. Annals of Glaciology 54, 191-199 (2013).

621 British Antarctic Survey. 2005. Antarctic Peninsula and Weddell Sea, 1:3,000,000 and 1:1,000,000 622 scale maps. BAS (Misc) 13A and 13B. Cambridge, British Antarctic Survey.

623 Cape, M.R., Vernet, M., Skvarca, P., Marinsek, S., Scambos, T. \& Domack, E. Foehn winds link 624 climate-driven warming to ice shelf evolution in Antarctica. Journal of Geophysical Research: 625 Atmospheres, 120(21), (2015).

626 Carrivick, J.L., Davies, B.J., Glasser, N.F., Nývlt, D. \& Hambrey, M.J., 2012. Late-Holocene changes 627 in character and behaviour of land-terminating glaciers on James Ross Island, Antarctica. Journal of 628 Glaciology, 58(212), pp.1176-1190.

629 Carrivick, J.L., Davies, B.J., James, W.H., Quincey, D.J. \& Glasser, N.F., 2016. Distributed ice 630 thickness and glacier volume in southern South America. Global and Planetary Change, 146, pp.122631132.

632 Cook, A. J. \& Vaughan, D. G. Overview of areal changes of the ice shelves on the Antarctic Peninsula 633 over the past 50 years. The Cryosphere 4, 77-98 (2010).

634 Cook, A. J., Holland, P. R., Meredith, M. P., Murray, T., Luckman, A. \& Vaughan, D. G. Ocean 635 forcing of glacier retreat in the western Antarctic Peninsula. Science 353, 283-286 (2016).

636 Cook, A. J., Fox, A. J., Vaughan, D. G. \& Ferrigno, J. G. Retreating glacier fronts on the Antarctic 637 Peninsula over the past half-century. Science 308, 541-544 (2005).

638 Cook, A. J., Vaughan, D. G., Luckman, A. J. \& Murray, T. A new Antarctic Peninsula glacier basin 639 inventory and observed area changes since the 1940s. Antarctic Science 26, 614-624 (2014).

640 Cook, A., Murray, T., Luckman, A., Vaughan, D., \& Barrand, N., A new 100-m Digital Elevation 641 Model of the Antarctic Peninsula derived from ASTER Global DEM: methods and accuracy 642 assessment. Earth System Science Data 4, 129-142 (2012).

643 Davies, B. J., Carrivick, J. L., Glasser, N. F., Hambrey, M. J. \& Smellie, J. L. Variable glacier response 644 to atmospheric warming, northern Antarctic Peninsula, 1988-2009. The Cryosphere 6, 1031-1048 645 (2012).

646 Davies, B.J., Golledge, N.R., Glasser, N.F., Carrivick, J.L., Ligtenberg, S.R., Barrand, N.E., Van Den 647 Broeke, M.R., Hambrey, M.J. \& Smellie, J.L., 2014. Modelled glacier response to centennial 648 temperature and precipitation trends on the Antarctic Peninsula. Nature Climate Change 4, 993 (2014).

649 Depoorter, M.A., Bamber, J.L., Griggs, J.A., Lenaerts, J.T.M., Ligtenberg, S.R.M., Van den Broeke, 650 M.R. \& Moholdt, G., Calving fluxes and basal melt rates of Antarctic ice shelves. Nature, 502, 89-92 651 (2013). 
652

653

654

655

656

657

658

659

660

661

662

663

664

665

666

667

668

669

670

671

672

673

674

675

676

677

678

679

680

681

682

683

684

685

686

687

688

689

690

691

692

Domack, E. W. et al. (Eds.), Antarctic Peninsula Climate Variability: Historical and Paleoenvironmental Perspectives, Washington, D.C., American Geophysical Union (Antarctic Research Series, 79). 1-13.

Driedger, C., \& Kennard, P.M. Glacier volume estimation on Cascade volcanoes: an analysis and comparison with other methods. Ann. Glaciol., 8, 59-64 (1986a).

Driedger, C.L., \& Kennard, P.M. Ice Volumes on Cascade Volcanoes: Mount Rainier, Mount Hood, Three Sisters, and Mount Shasta Washington: U.S. Geological Survey Professional Paper, 1365 (1986b).

Drewry, D. J., Antarctic Ice Sheet - Aspects of Current Configuration and Flow. In. Gardner, R. \& Scoging, H. (Eds.) Mega-Geomorphology. British Geomorphological Research Group. Clarenden Press pp. 18-38 (1983).

Ely, J.C. \& Clark, C.D. Flow-stripes and foliations of the Antarctic ice sheet. Journal of Maps 12, 249259 (2016).

Engel, Z., Nývlt, D. \& Láska, K. Ice thickness, areal and volumetric changes of Davies Dome and Whisky Glacier in 1979-2006 (James Ross Island, Antarctic Peninsula). Journal of Glaciology 58, 904914 (2012).

Farinotti, D. \& Huss, M. An upper-bound estimate for the accuracy of glacier volume-area scaling. The Cryosphere, 7(6), 1707-1720 (2013).

Farinotti, D. et al. A method to estimate the ice volume and ice-thickness distribution of alpine glaciers. Journal of Glaciology, 55(191), 422-430 (2009).

Farinotti, D., Corr, H. \& Gudmundsson, G. H., The ice thickness distribution of Flask Glacier, Antarctic Peninsula, determined by combining radio-echo soundings, surface velocity data and flow modelling. Annals of Glaciology 54, 18-24 (2013).

Ferrigno, J. G. et al. Coastal-Change and Glaciological Map of the Trinity Peninsula Area and South Shetland Islands, Antarctica: 1843-2001. USGS, Denver (2006).

Fischer, A. \& Kuhn, M. Ground-penetrating radar measurements of 64 Austrian glaciers between 1995 and 2010. Annals of Glaciology, 54(64), 179-188 (2013).

Fretwell, L. O., et al. Bedmap2: improved ice bed, surface and thickness datasets for Antarctica. The Cryosphere 7, 375-393 (2013).

Gardner, A.S., Moholdt, G., Cogley, J.G., Wouters, B., Arendt, A.A., Wahr, J., Berthier, E., Hock, R., Pfeffer, W.T., Kaser, G. \& Ligtenberg, S.R. A reconciled estimate of glacier contributions to sea level rise: 2003 to 2009. Science 340, 852-857 (2013).

Glasser, N. F., Scambos, T. A., Bohlander, J. A., Truffer, M., Pettit, E. C., \& Davies, B. J. From iceshelf tributary to tidewater glacier: continued rapid glacier recession, acceleration and thinning of Röhss Glacier following the 1995 collapse of the Prince Gustav Ice Shelf on the Antarctic Peninsula. Journal of Glaciology 57, 397-406 (2011).

Golledge, N.R., Menviel, L., Carter, L., Fogwill, C.J., England, M.H., Cortese, G. \& Levy, R.H. Antarctic contribution to meltwater pulse $1 \mathrm{~A}$ from reduced Southern Ocean overturning. Nature Communications 5, 5107 (2014).

Golledge, N.R., Kowalewski, D.E., Naish, T.R., Levy, R.H., Fogwill, C.J. and Gasson, E.G.. The multi-millennial Antarctic commitment to future sea-level rise. Nature 526421 (2015). 
Gowan, E.J., Tregoning, P., Purcell, A., Lea, J., Fransner, O.J., Noormets, R. and Dowdeswell, J.A.,.

694 ICESHEET 1.0: a program to produce paleo-ice sheet reconstructions with minimal assumptions.

695 Geoscientific Model Development 9, 1673-1682 (2016).

696 Heroy, D. C. \& Anderson, J. B. Ice-sheet extent of the Antarctic Peninsula region during the Last

697 Glacial Maximum (LGM) - Insights from glacial geomorphology. GSA Bulletin 117, 1497-1512

698 (2005).

699 Hock, R., de Woul, M., Radic, V. \& Dyurgerov, M. Mountain glaciers and ice caps around Antarctica

700

701

702

703 make a large sea-level rise contribution. Geophysical Research Letters 36, L07501 (2009).

Huber, J., Cook, A.J., Frank, P. and Zemp, M. A complete glacier inventory of the Antarctic Peninsula based on Landsat 7 images from 2000 to 2002 and other preexisting data sets. Earth System Science Data 9, 115 (2017).

704

705

706

707

708

709

Huss, M. \& Farinotti, D. A high-resolution bedrock map for the Antarctic Peninsula. The Cryosphere 8, 1261-1273 (2014).

Hutchinson, M. A new procedure for gridding elevation and stream line data with automatic removal of spurious pits. Journal of Hydrology, 106(3), pp.211-232 (1989).

Ivins, E. R., Watkins, M. M., Yuan, D.-N., Dietrich, R., Casassa, G. \& Rülke, A., On-land ice loss and glacial isostatic adjustment at the Drake Passage: 2003-2009. J. Geophys. Res. 116, B02403 (2011).

James, W. H. M. \& Carrivick, J. L. Automated modelling of spatially-distributed glacier ice thickness and volume. Computers \& Geosciences 92, 90-103 (2016).

712 Kingslake, J., Ely, J.C., Das, I. \& Bell, R.E. Widespread movement of meltwater onto and across

713 Antarctic ice shelves. Nature 544, 349 (2017).

714 Kunz, M. et al. Multi-decadal glacier surface lowering in the Antarctic Peninsula. Geophys. Res. Lett.

715 39, L19502 (2012).

$716 \mathrm{Li}, \mathrm{H}$. et al. An extended "perfect-plasticity" method for estimating ice thickness along the flow line of 717 mountain glaciers. Journal of Geophysical Research-Earth Surface, 117(F01020) (2012).

718 Linsbauer, A. et al. The Swiss Alps without glaciers - a GIS-based modelling approach for

719 reconstruction of glacier beds. In: Proceedings of Geomorphometry 2009, Zurich, Switzerland. (2009).

720 Linsbauer, A., Paul, F. \& Haeberli, W. Modeling glacier thickness distribution and bed topography

721

722

723

over entire mountain ranges with GlabTop: Application of a fast and robust approach. Journal of

Geophysical Research, 117(F3) (2012).

724 Part II -Topical Studies in Oceanography 55, 1964-1987 (2008).

725

726

727

728

729

730

Meier, M. F. et al. Glaciers dominate eustatic sea-level rise in the 21st century. Science, 317(5841), 1064-1067 (2007).

Meredith, M. P., \& King, J. C. Rapid climate change in the ocean west of the Antarctic Peninsula during the second half of the 20th century. Geophysical Research Letters, 32(19) (2005).

Morlighem, M., Rignot, E., Seroussi, H., Larour, E., Ben Dhia, H. and Aubry, D. A mass conservation approach for mapping glacier ice thickness. Geophysical Research Letters 38 (2011).

Morris, E. M. \& Vaughan, A. P. M. Spatial and temporal variation of surface temperature on the 
733

734

735

736

737

738

739

740

741

742

743

744

745

746

747

748

749

750

751

752

753

754

755

756

757

758

759

760

761

762

763

764

765

766

767

768

769

770

771

772

773

Peninsula climate variability: historical and palaeoenvironmental perspectives. American Geophysical Union, Antarctic Research Series, Volume 79, Washington, D.C., pp. 61-68. (2003).

Nye, J. The flow of a glacier in a channel of rectangular, elliptic or parabolic cross-section. Journal of Glaciology 5, 661-690 (1965).

Ó Cofaigh, C. et al. Reconstruction of ice-sheet changes in the Antarctic Peninsula since the Last Glacial Maximum. Quaternary Science Reviews 100, 87-110 (2014).

Oliva, M., Navarro, F., Hrbáček, F., Hernández, A., Nývlt, D., Pereira, P., Ruiz-Fernández, J. \& Trigo, R. Recent regional climate cooling on the Antarctic Peninsula and associated impacts on the cryosphere. Science of the Total Environment 580, 210-223 (2017).

Operation Ice-Bridge (2016) website: http://www.nasa.gov/mission_pages/icebridge/index.html last visited May 2016.

Paolo, F.S., Fricker, H.A. \& Padman, L. Volume loss from Antarctic ice shelves is accelerating. Science 348, 327-331 (2015).

Pfeffer, W. T. et al. The Randolph Glacier Inventory: a globally complete inventory of glaciers. Journal of Glaciology, 60(221), 537-552 (2014).

Pritchard, H. D. \& Vaughan, D. G. Widespread acceleration of tidewater glaciers on the Antarctic Peninsula. Journal of Geophysical Research-Earth Surface 112, F03S29, 01-10 (2007).

Pritchard, H. D., Arthern, R. J., Vaughan, D. G., \& Edwards, L. A. Extensive dynamic thinning on the margins of the Greenland and Antarctic ice sheets. Nature 461, 971-975 (2009).

Pritchard, H., Ligtenberg, S.R.M., Fricker, H.A., Vaughan, D.G., Van den Broeke, M.R. \& Padman, L.. Antarctic ice-sheet loss driven by basal melting of ice shelves. Nature, 484(7395), 502 (2012).

Radić, V. \& Hock, R. Regional and global volumes of glaciers derived from statistical upscaling of glacier inventory data. Journal of Geophysical Research: Earth Surface 115, F01010 (2010).

Radic, V. \& Hock, R. Regionally differentiated contribution of mountain glaciers and ice caps to future sea-level rise. Nature Geosci 4, 91-94 (2011).

Raper, S. C., \& Braithwaite, R. J. Low sea-level rise projections from mountain glaciers and icecaps under global warming. Nature, 439(7074), 311-313 (2006).

Rignot, E., Mouginot, J. \& Scheuchl, B. Ice flow of the Antarctic ice sheet. Science, 333(6048), 14271430 (2011).

Rignot, E., Jacobs, S., Mouginot, J., \& Scheuchl, B. Ice-shelf melting around Antarctica. Science, 341(6143), 266-270 (2013).

Rott, H., Müller, F. \& Floricioiu, D. The imbalance of glaciers after disintegration of Larsen B ice shelf, Antarctic Peninsula. The Cryosphere 5, 125-134 (2011).

Sasgen, I., Konrad, H., Ivins, E.R., Van den Broeke, M.R., Bamber, J.L., Martinec, Z. \& Klemann, V.. Antarctic ice-mass balance 2003 to 2012: regional reanalysis of GRACE satellite gravimetry measurements with improved estimate of glacial-isostatic adjustment based on GPS uplift rates. The Cryosphere 7, 1499-1512 (2013).

Scambos, T., Hulbe, C. \& Fahnestock, M. Climate-induced ice shelf disintegration in the Antarctic Peninsula, in: Domack, E.W. et al. (Eds.), Antarctic Peninsula climate variability: historical and palaeoenvironmental perspectives. American Geophysical Union, Antarctic Research Series, Volume 79, Washington, D.C., pp. 79-92 (2003). 
774

775

776

777

778

779

780

781

782

783

784

785

786

787

788

789

790

791

792

793

794

795

796

797

798

799

800

801

802

803

804

805

806

807

808

809

810

811

812

813

814
Scambos, T.A., Berthier, E., Haran, T., Shuman, C.A., Cook, A.J., Ligtenberg, S. \& Bohlander, J.. Detailed ice loss pattern in the northern Antarctic Peninsula: widespread decline driven by ice front retreats. The Cryosphere 8, 2135-2145 (2014).

Schannwell, C., Cornford, S., Pollard, D. \& Barrand, N.E. Dynamic response of Antarctic Peninsula Ice Sheet to potential collapse of Larsen C and George VI ice shelves. The Cryosphere 12, 2307-2326 (2018).

Schoof, C. Ice sheet grounding line dynamics: Steady states, stability, and hysteresis. Journal of Geophysical Research: Earth Surface 112 (2007).

Shepherd, A., Ivins, E.R., Geruo, A., Barletta, V.R., Bentley, M.J., Bettadpur, S., Briggs, K.H., Bromwich, D.H., Forsberg, R., Galin, N. \& Horwath, M. A reconciled estimate of ice-sheet mass balance. Science 338, 1183-1189 (2012).

Schmidtko, S., Heywood, K. J., Thompson, A. F. \& Aoki, S. Science 346, 1227-1231 (2014).

Skvarca, P. \& De Angelis, H. Impact assessment of regional climatic warming on glaciers and ice shelves of the northeastern Antarctic Peninsula, in: Domack, E.W., et al. (Eds.), Antarctic Peninsula climate variability: historical and palaeoenvironmental perspectives. American Geophysical Union, Antarctic Research Series, Volume 79, Washington, D.C., pp. $69-78$ (2003).

Turner, J., Lu, H., White, I., King, J.C., Phillips, T., Hosking, J.S., Bracegirdle, T.J., Marshall, G.J., Mulvaney, R. \& Deb, P. Absence of 21st century warming on Antarctic Peninsula consistent with natural variability. Nature 535, 411 (2016).

Turner, J. et al. Antarctic climate change and the environment: an update. Polar Record 50, 237-259 (2013).

Turner, J. et al., Antarctic Climate Change and the Environment. Scientific Committee on Antarctic Research, Cambridge (2009).

van den Broeke, M. Strong surface melting preceded collapse of Antarctic Peninsula ice shelf. Geophysical Research Letters, 32(12), (2005).

Van Wessem, J.M., Ligtenberg, S., Reijmer, C.H., Van De Berg, W.J., Van Den Broeke, M.R., Barrand, N.E., Thomas, E.R., Turner, J., Wuite, J., Scambos, T.A. \& Van Meijgaard, E.. The modelled surface mass balance of the Antarctic Peninsula at $5.5 \mathrm{~km}$ horizontal resolution. The Cryosphere 10, 271-285 (2016).

Vieli, A. \& Nick, F.M., 2011. Understanding and modelling rapid dynamic changes of tidewater outlet glaciers: issues and implications. Surveys in Geophysics 32, 437-458 (2011).

Wouters, B., Martin-Español, A., Helm, V., Flament, T., van Wessem, J.M., Ligtenberg, S.R., Van den Broeke, M.R. \& Bamber, J.L. Dynamic thinning of glaciers on the Southern Antarctic Peninsula. Science 348, 899-903 (2015).

Zekollari, H., \& Huybrechts, P. On the climate-geometry imbalance, response time and volume-area scaling of an alpine glacier: insights from a 3-D flow model applied to Vadret da Morteratsch, Switzerland. Annals of Glaciology 56, 51-62 (2015). 


\section{ACKNOWLEDGEMENTS}

816 Development of the perfect plasticity model was supported by a NERC PhD studentship

817 (NE/K500847/1) to WJ. Alison Cook provided the DEM and the glacier outlines for areas north of

$81870^{\circ} \mathrm{S}$. We thanks the Bedmap2 team for their publically-available data. We thank Matthias Huss and 819 Daniel Farinotti for their data made available via their supplementary information.

820

821

822

823

824

825

826

827

828

829

830

831

832

833

834

835

836

837 


\begin{tabular}{ll}
\hline Mainland Antarctic Peninsula \\
\hline TP-West & Trinity Peninsula west of main divide \\
TP-East & Trinity Peninsula east of main divide \\
GL-West & Graham Land west of main divide \\
GL-East & Graham Land east of main divide \\
PL-west & Palmer Land west of main divide \\
PL-east & Palmer Land east of main divide \\
\hline Surrounding Islands \\
\hline N & Andersson, Bransfield, Dundee, Joinville, Jonasson, D'Urville \\
N-west & South Shetland Islands, Deception, Low, Smith, Snow \\
N-east & James Ross, Eagle, Lockyer, Snow Hill, Vega \\
C-west & Adelaide, Anvers, Astrolabe, Belding, Brabant, Butler, Christiana, Dubois, Hoseason, Horseshoe, Krogh, \\
& Larrouy, Lavoisier, Liard, Liege, Millerand, Pitt, Pourquois Pass, Rabot, Renaud, Tower, Trinity, Two \\
C-east & Hummock, Watkins, Wiencke \\
S-west & Dollerman, Ewing, Francis, Gipps, Hearst, Robertson, Seal Nunataks, Steele, Tonkin \\
A & Case, Charcot, DeAtley, Dorsey, Eklund Islands, Latady, Rothschild, Smyley, Spaatz \\
\hline
\end{tabular}

\section{1}

842

843

844

845

846

847

848

\begin{tabular}{|c|c|c|c|c|c|c|}
\hline \multirow[b]{2}{*}{ Region } & \multicolumn{2}{|c|}{ This study } & \multicolumn{2}{|c|}{ Bedmap2 (Fretwell et al., 2013) } & \multicolumn{2}{|c|}{ Huss and Farinotti (2014) } \\
\hline & $\begin{array}{l}\text { Mean ice } \\
\text { thickness }\end{array}$ & $\begin{array}{l}\text { Maximum ice } \\
\text { thickness }\end{array}$ & $\begin{array}{l}\text { Mean ice } \\
\text { thickness }\end{array}$ & $\begin{array}{l}\text { Maximum ice } \\
\text { thickness }\end{array}$ & $\begin{array}{l}\text { Mean ice } \\
\text { thickness }\end{array}$ & $\begin{array}{l}\text { Maximum ice } \\
\text { thickness }\end{array}$ \\
\hline & (m) & (m) & (m) & (m) & $(\mathrm{m})$ & (m) \\
\hline \multicolumn{7}{|l|}{ Mainland } \\
\hline TP-West & 459 & 1457 & 187 & 484 & 277 & 1075 \\
\hline TP-East & 423 & 1577 & 141 & 521 & 260 & 1080 \\
\hline GL-West & 373 & 2216 & 130 & 985 & 251 & 1316 \\
\hline GL-East & 563 & 2136 & 223 & 1291 & 354 & 1983 \\
\hline PL-west & 1305 & 2668 & 892 & 2451 & & \\
\hline PL-east & 571 & 2521 & 937 & 3171 & $370 *$ & $1835^{*}$ \\
\hline \multicolumn{7}{|c|}{ Surrounding islands } \\
\hline $\mathrm{N}$ & 480 & 1603 & 227 & 477 & 256 & 656 \\
\hline $\mathrm{N}$-west & 242 & 1113 & 56 & 391 & & \\
\hline N-east & 335 & 1719 & 116 & 436 & 234 & 920 \\
\hline C-west & 516 & 1914 & 184 & 738 & 228 & 1159 \\
\hline C-east & 385 & 1594 & 258 & 435 & $14^{*}$ & $605^{\star}$ \\
\hline S-west & 397 & 2166 & 326 & 589 & & \\
\hline A & 569 & 2304 & 323 & 1640 & & \\
\hline
\end{tabular}

Table 1. Explanation of geographical codes and groupings of major glacier regions for the Antarctic Peninsula and surrounding islands used in this study.

*These values of Huss and Farinotti's dataset only include calculations covering a small part of these

851 regions.

Table 2: Comparison of mean and maximum ice thickness per major region as modelled by this study, Bedmap2 (Fretwell et al., 2013) and Huss and Farinotti (2014). All ice thickness estimates have a worst-case uncertainty of $\pm 31 \%$.

856

857 


\begin{tabular}{|c|c|c|c|c|c|c|c|c|c|c|}
\hline \multirow[b]{2}{*}{ Region } & \multirow[b]{2}{*}{$\begin{array}{l}\text { Ice volume } \\
\left(\mathrm{km}^{3}\right)\end{array}$} & \multicolumn{3}{|l|}{ This study } & \multicolumn{3}{|c|}{ Bedmap2 (Fretwell et al., 2013) } & \multicolumn{3}{|c|}{ Huss and Farinotti (2014) } \\
\hline & & $\begin{array}{l}\text { Ice volume } \\
<0 \text { m.asl } \\
\left(\mathrm{km}^{3}\right)\end{array}$ & $\begin{array}{l}\text { Ice mass } \\
\text { (Gt) }\end{array}$ & $\begin{array}{l}\text { Sea level } \\
\text { equivalent } \\
(\mathrm{mm})\end{array}$ & $\begin{array}{l}\text { Ice volume } \\
\left(\mathrm{km}^{3}\right)\end{array}$ & $\begin{array}{l}\text { Ice volume } \\
<0 \text { m.asl } \\
\left(\mathrm{km}^{3}\right)\end{array}$ & $\begin{array}{l}\begin{array}{l}\text { Sea level } \\
\text { equivalent } \\
\text { (mm) }\end{array} \\
\end{array}$ & $\begin{array}{l}\text { Ice volume } \\
\left(\mathrm{km}^{3}\right)\end{array}$ & $\begin{array}{l}\text { Ice volume } \\
<0 \text { m.asl } \\
\left(\mathrm{km}^{3}\right)\end{array}$ & $\begin{array}{l}\text { Sea level } \\
\text { equivalent } \\
\text { (mm) }\end{array}$ \\
\hline TP-west & 1,211 & 282 & 791 & 2 & 494 & 13 & 2 & 745 & 41 & 2 \\
\hline TP-east & 1,362 & 449 & 778 & 2 & 494 & 13 & 2 & 929 & 160 & 2 \\
\hline GL-west & 8,843 & 1,639 & 6,138 & 17 & 3,070 & 69 & 10 & 5,972 & 639 & 13 \\
\hline GL-east & 16,208 & 4,588 & 9,900 & 27 & 6,441 & 896 & 18 & 10,275 & 2,111 & 19 \\
\hline PL-west & 122,772 & 34,013 & 75,623 & 209 & 117,224 & 21,331 & 311 & & & \\
\hline PL-east & 109,810 & 3,424 & 90,641 & 250 & 197,225 & 82,130 & 373 & & & \\
\hline sum mainland & 260,207 & 44,395 & 183,871 & 508 & 324,948 & 104,452 & 715 & 17,922 & 2,951 & 35 \\
\hline$N$ & 1,121 & 541 & 493 & 1 & 539 & 122 & 1 & 625 & 149 & 1 \\
\hline N-west & 663 & 208 & 387 & 1 & 146 & 6 & 0 & & & \\
\hline $\mathrm{N}$-east & 662 & 138 & 447 & 1 & 253 & 18 & 1 & 583 & 155 & 1 \\
\hline C-west & 4,003 & 1,794 & 1,881 & 5 & 1,571 & 176 & 5 & 2,047 & 228 & 4 \\
\hline C-east & 717 & 284 & 369 & 1 & 553 & 168 & 1 & & & \\
\hline S-west & 2,529 & 1,091 & 1,224 & 3 & 4,373 & 1,374 & 10 & & & \\
\hline A & 27,078 & 13,380 & 11,671 & 32 & 15,324 & 3,916 & 37 & & & \\
\hline sum islands & 36,772 & 17,436 & 16,472 & 46 & 22,760 & 5,778 & 55 & 3,255 & 533 & 6 \\
\hline sum total & 296,979 & 61,831 & 200,343 & 553 & 347,708 & 110,231 & 770 & 21,177 & 3,484 & 42 \\
\hline
\end{tabular}

858

859 Table 3. Summary per major mainland and surrounding island region of total ice volume, ice volume 860 below sea level and maximum potential sea-level equivalent (SLE) according to the modelling of this 861 study, Bedmap2 (Fretwell et al., 2013) data, and the modelling of Huss and Farinotti (2014). All 862 863 volumes and sea level equivalent estimates have a worst-case uncertainty of $\pm 20 \%$.

864

865

866

867

868

869

870

871

872 


\section{FIGURES}

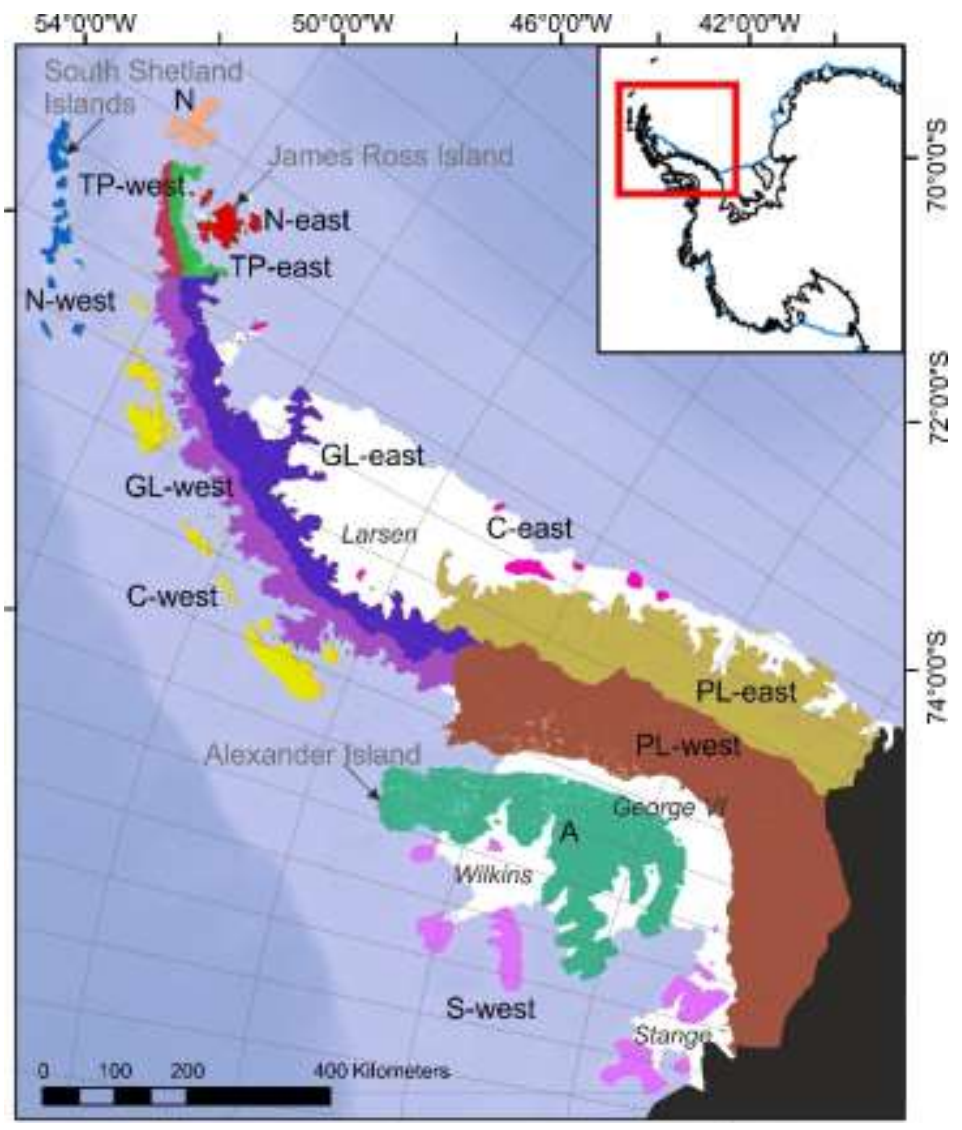

875

876 Figure 1. Major glacier regions across the Antarctic Peninsula as used in this study to spatially 877 discriminate ice thickness, bed topography, ice volume and potential sea level contributions.

878 Surrounding islands are grouped spatially and the labelled codes for these groups are expanded in 879 Table 1.

880

881 


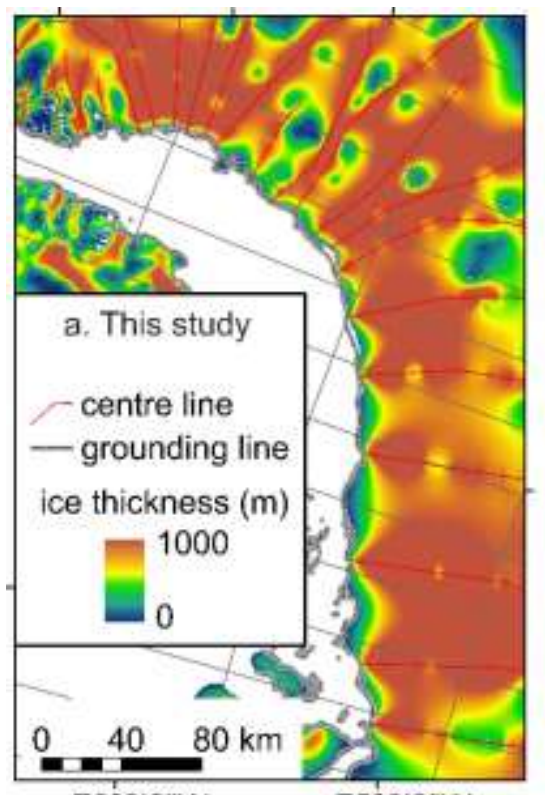

$76^{\circ} 0^{\circ} 0^{\prime \prime} \mathrm{W}$

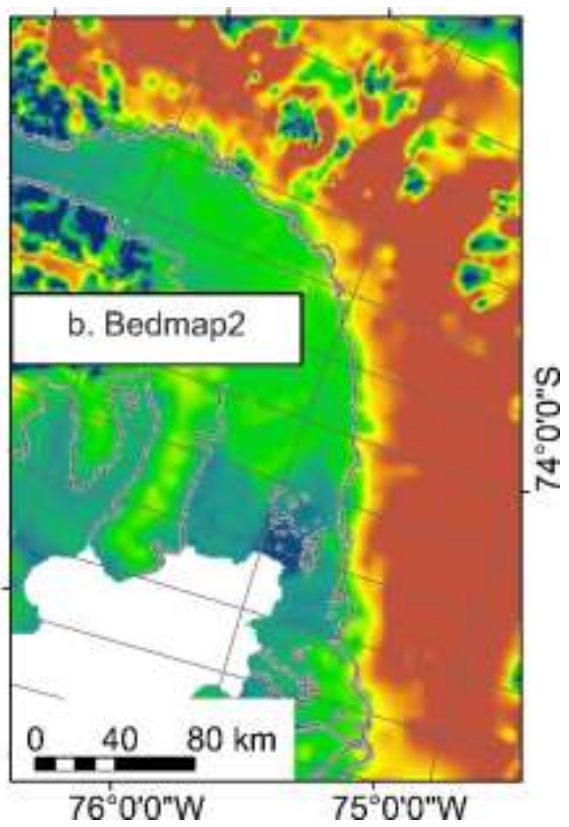

883

884 Figure 2. Example of multiple centrelines per single glacier outline artificially introduced to 885 accommodate application of the VOLTA model to wide, low-angle and coalescing glaciers that are 886 typical of the southern part of the Antarctic Peninsula, in this case on the mainland opposite the south 887 coast of Alexander Island. The resultant VOLTA-computed ice thickness (A) matches the magnitude 888 and spatial pattern of ice thickness from Bedmap2 (B) well. Grounding lines are from Rignot et al. 889 (2011). Bedmap2 data is from Fretwell et al. (2013).

890

891

892

893

894

895

896 

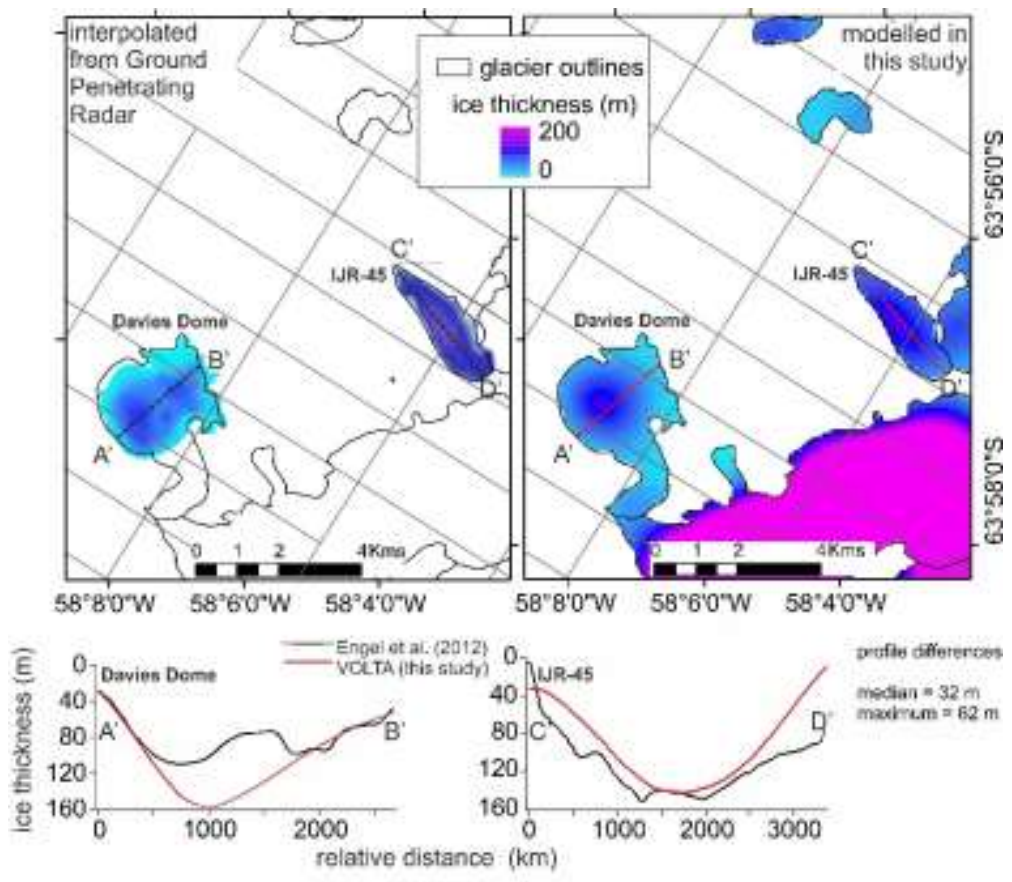

898 Figure 3. Comparison of ice thickness modelled in this study with that from Engel et al. (2012) who 899 interpolated between ground penetrating radar data on Davies Dome ice cap and IJR-45 valley glacier, 900 both on the Ulu Peninsula on James Ross Island. The ice thickness transects are chosen to closely 901 follow GPR lines so as to exclude interpolation error from these transect comparisons. 

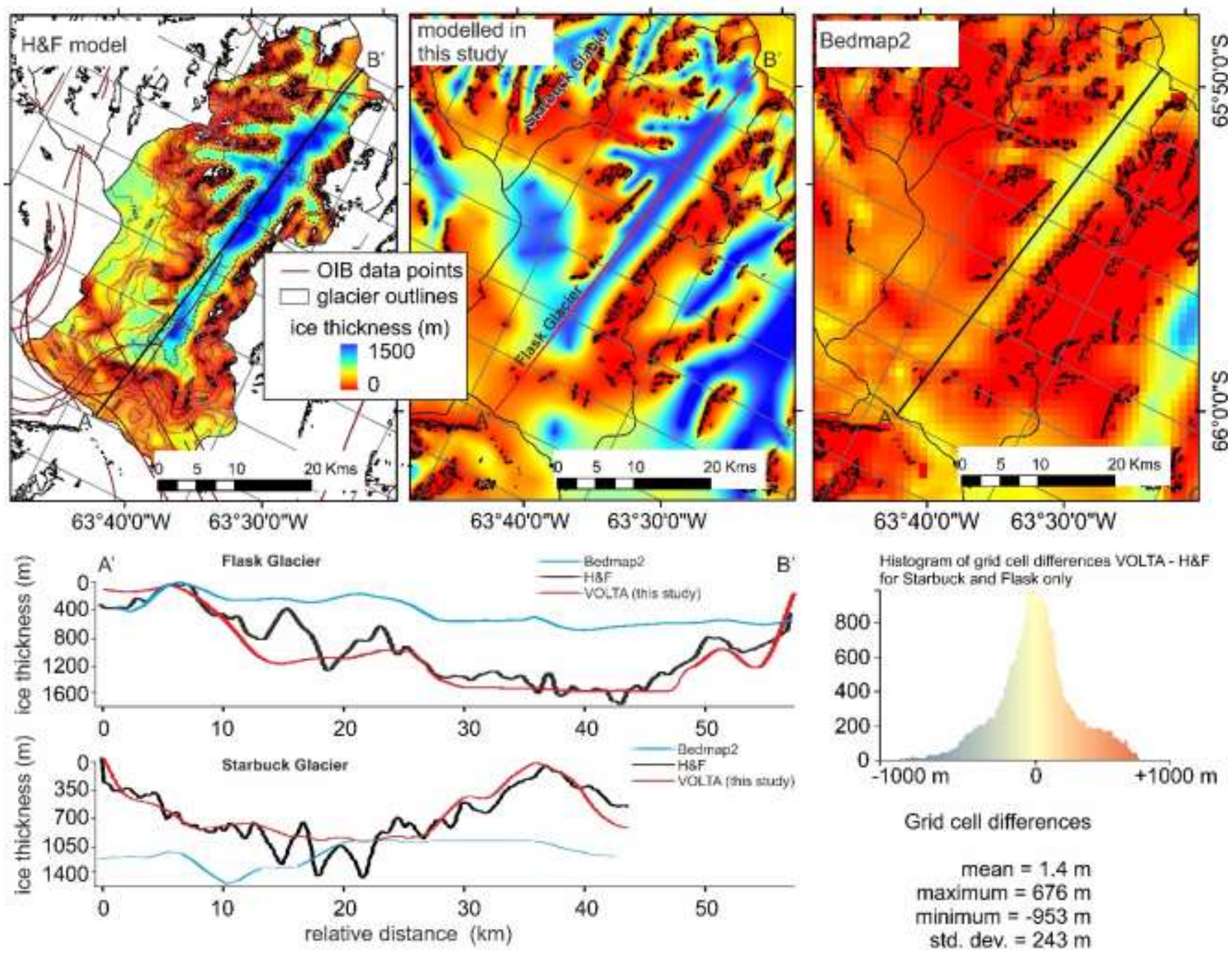

Grid cell differences

$$
\begin{array}{r}
\text { mean }=1.4 \mathrm{~m} \\
\text { maximum }=676 \mathrm{~m} \\
\text { minimum }=-953 \mathrm{~m} \\
\text { std. dev. }=243 \mathrm{~m}
\end{array}
$$

Figure 4. Comparison of ice thickness modelled in this study with that from Farinotti et al. (2013, 2014) who optimised their ice thickness model using ground penetrating radar data and ice velocity 906 data on Flask Glacier and on Starbuck Glacier, both of which are tidewater glaciers. The glacier outline 907 at the end of the transect and at point B' is determined by the grounding line, as mapped by Rignot et 908 al. (2011).

909

910

911

912 

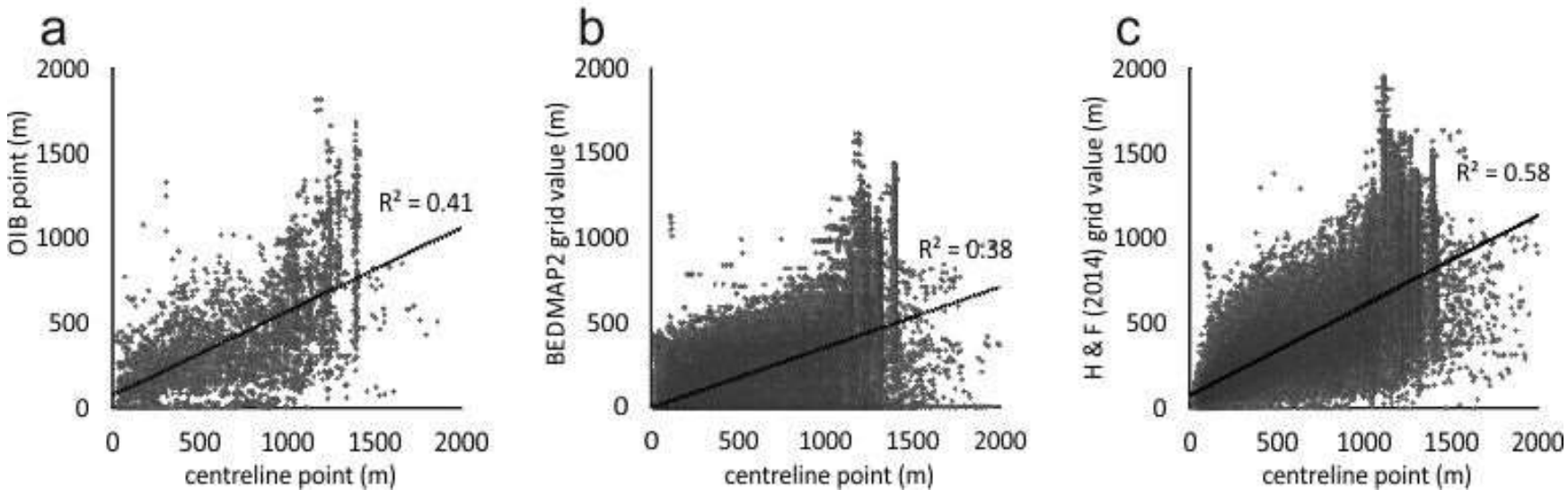

914 Figure 5. Cross-over analysis of ice thickness for our modelled glacier centreline points $(\mathrm{n}=81,463)$

915 and closest (if within $500 \mathrm{~m}$ ) Operation Ice-Bridge (2016) points (a). For comparison, the

916 corresponding ice thickness grid cell values of Bedmap2 (Fretwell et al., 2013) ice thickness and Huss 917 and Farinotti's (2014) ('H\&F') ice thickness at each of these centreline points are also shown in panels 918 b and c, respectively. 

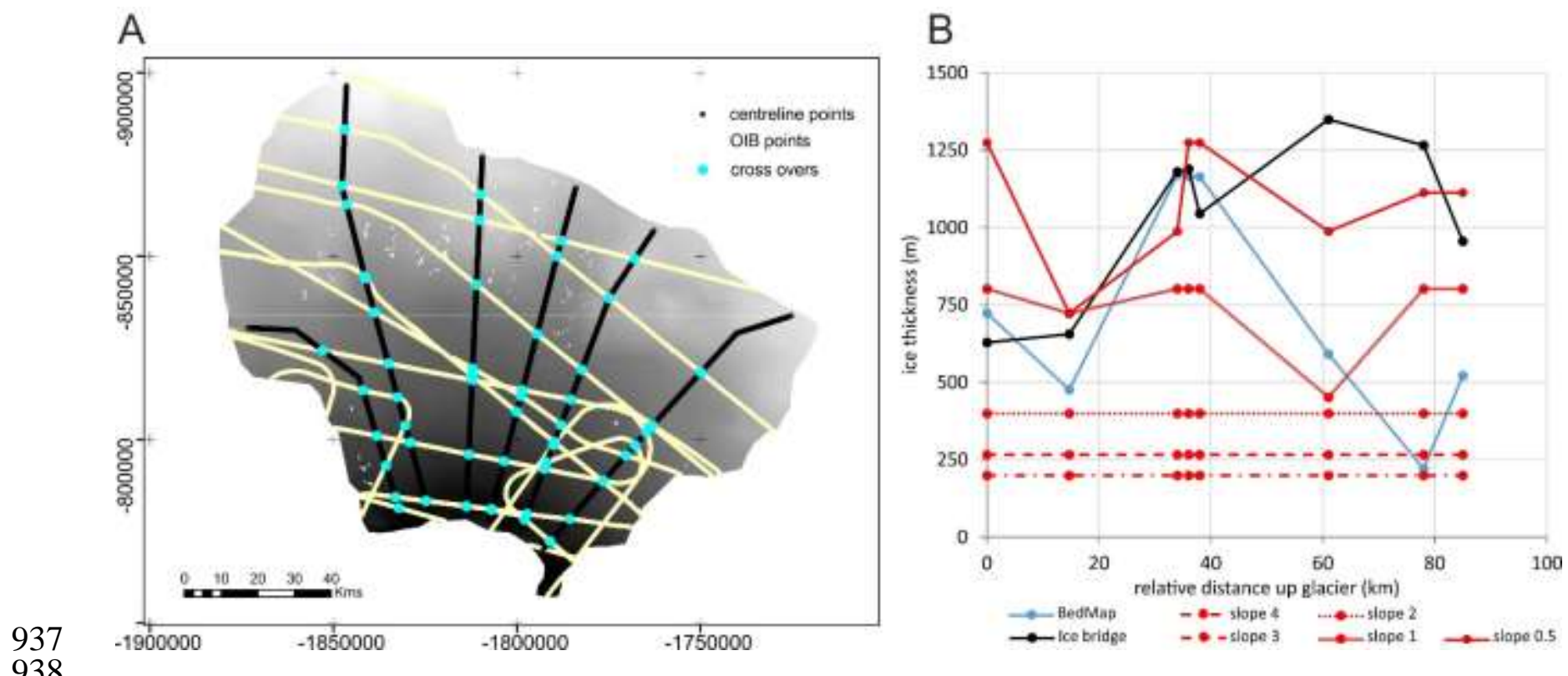

Figure 6. Cross-over analysis of ice thickness for our modelled glacier centreline points on the largest (area) single glacier in Palmer Land (A) illustrating the very low slope threshold values needed to 941 generate an ice thickness estimate with a perfect plasticity model and the unrealistic nature of these 942 estimates (B). 


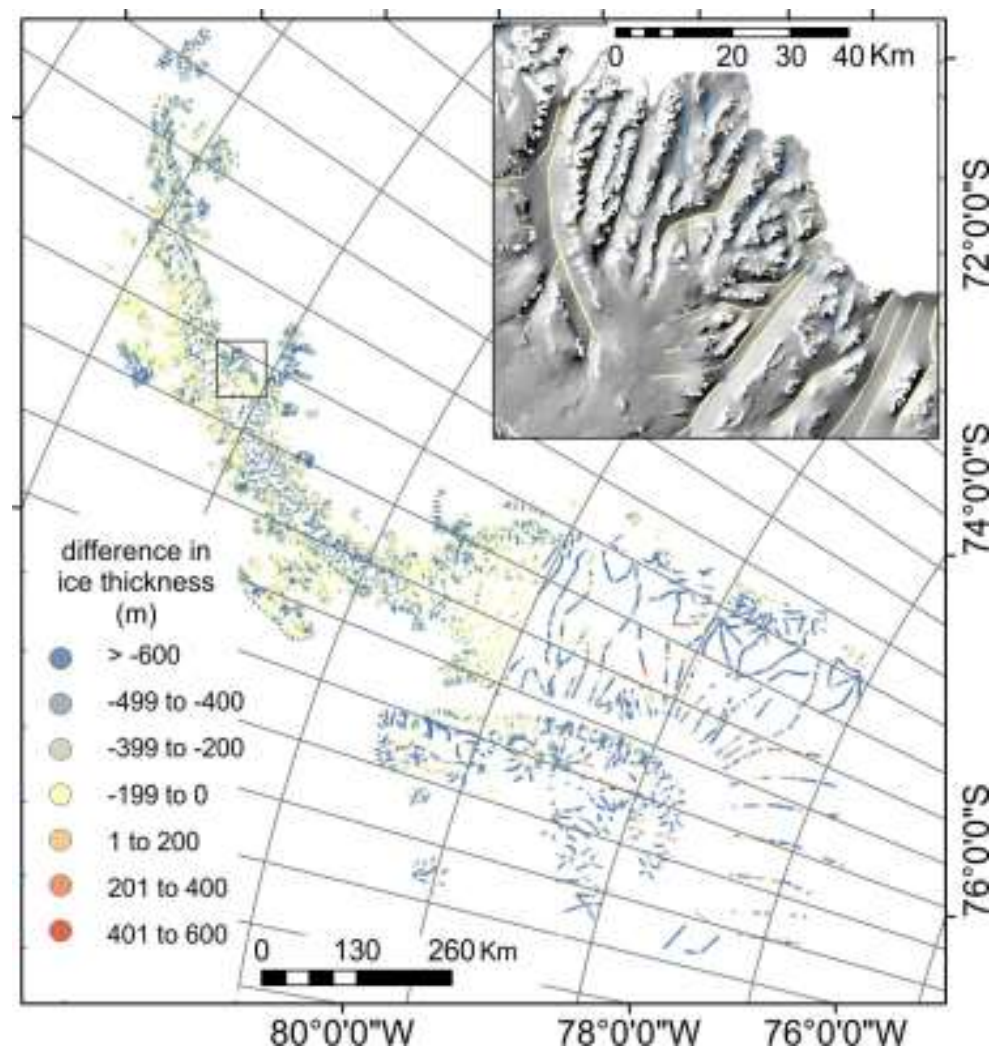

952

953 Figure 7. Spatial pattern of difference of ice thickness modelled on centreline points in this study with 954 the nearest (if within $500 \mathrm{~m}$ ) Operation Ice-Bridge (2016) ice thickness point. Inset is chosen to be 955 same area as emphasized by Huss and Farinotti (2014) for its subglacial trough topography.

956

957 
a
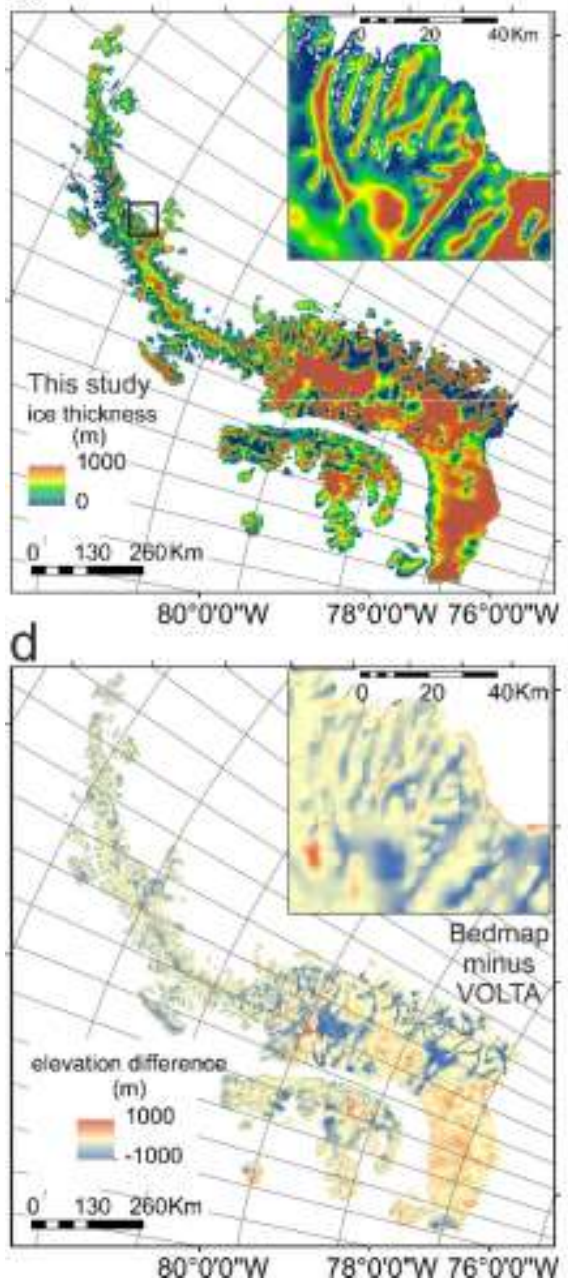

b
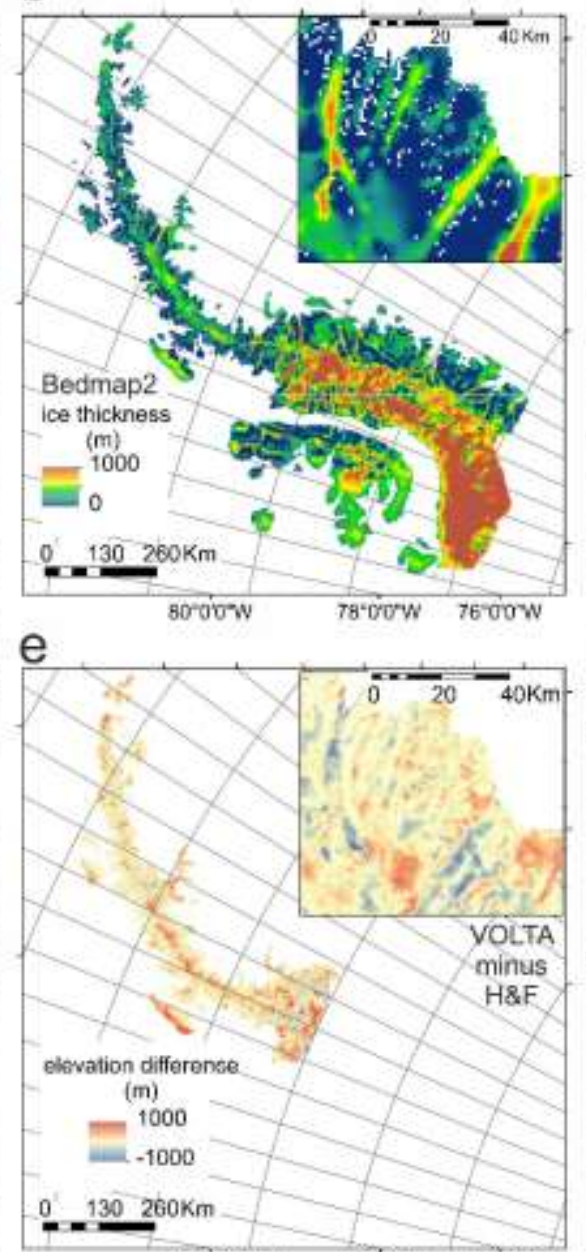

$80^{\circ} 00^{\circ} \mathrm{W} \quad 78^{\circ} 0^{\circ} \mathrm{O}^{\circ} \mathrm{W} 76^{\circ} 0^{\circ} 0^{\circ} \mathrm{W}$
C

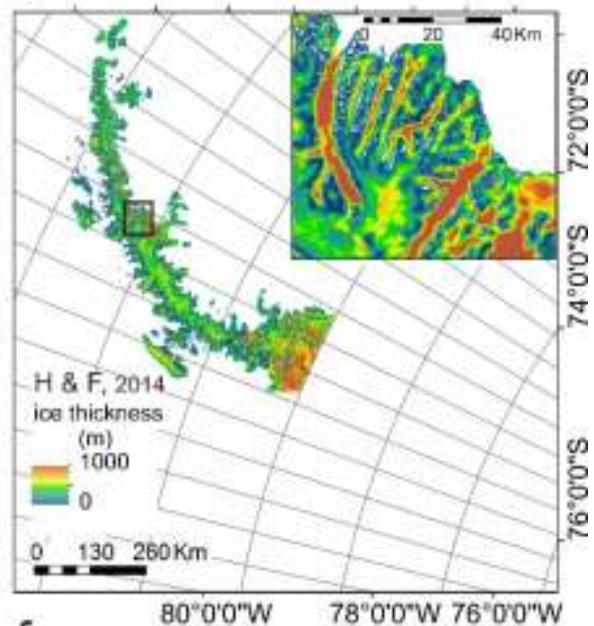

$f$

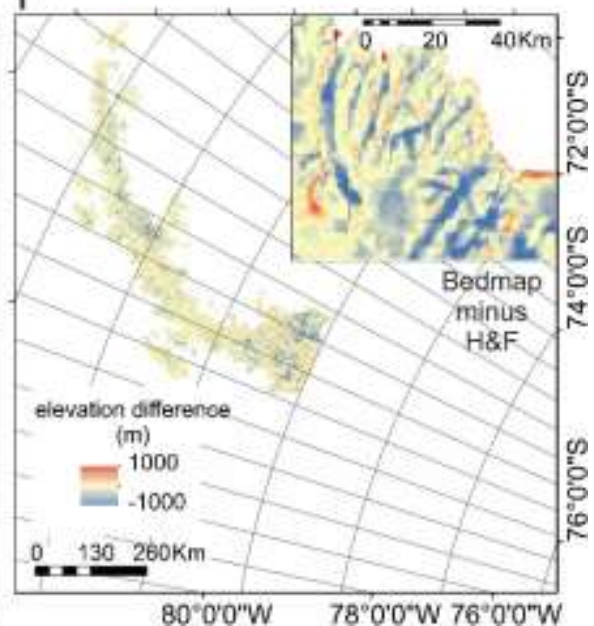

Figure 8. Gridded ice thickness modelled in this study (a) the Bedmap2 (Fretwell et al., 2013) dataset (b), and modelled by Huss and Farinotti (2014) ('H\&F') (c). Differences in ice thickness between Bedmap2 and this study, between Huss and Farinotti and this study, and between Huss and Farinotti and Bedmap2 are shown in panels $\mathrm{d}$, e and f, respectively. Colour scales are identical in all panels and in all insets. Inset is chosen to be same area as emphasised by Huss and Farinotti for its subglacial trough topography. 


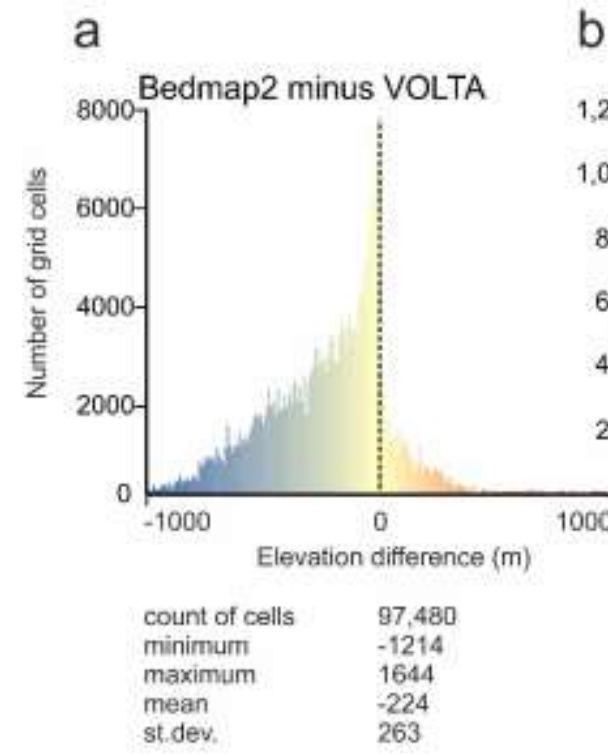

$b$
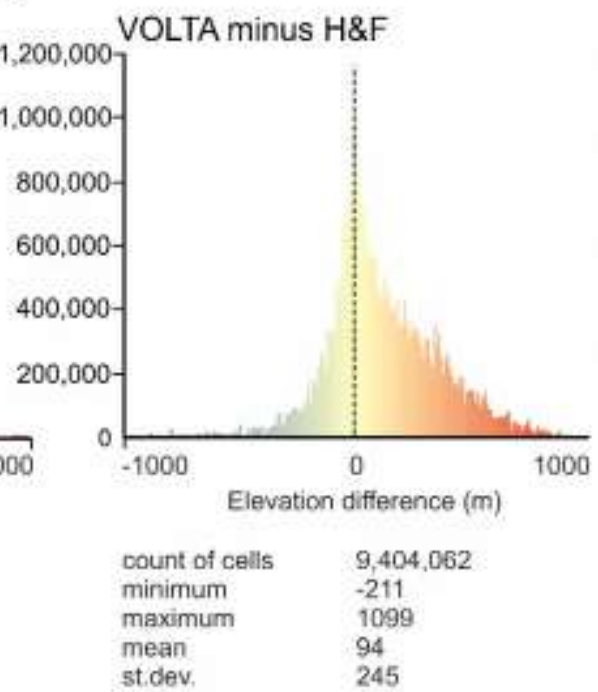

C

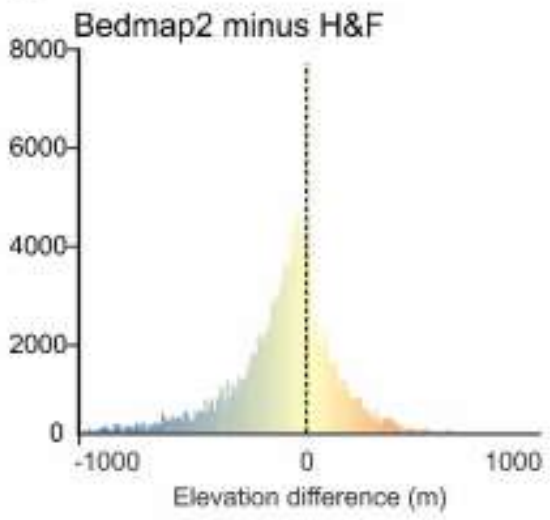

count of cells $\quad 97,480$

minimum $\quad-1655$ maximum $\quad 961$

mean -117

st.dev. 220

968 Figure 9. Histogram comparison of grid cell values between the modelled ice thickness of this study 969 and Bedmap2 (a), between this study and the ice thickness modelled by Huss and Farinotti (2014) 970 ('H\&F') (b) and Huss and Farinotti and Bedmap2 (c). Bars are coloured to match the elevation 971 differences as mapped in Figure 4. 

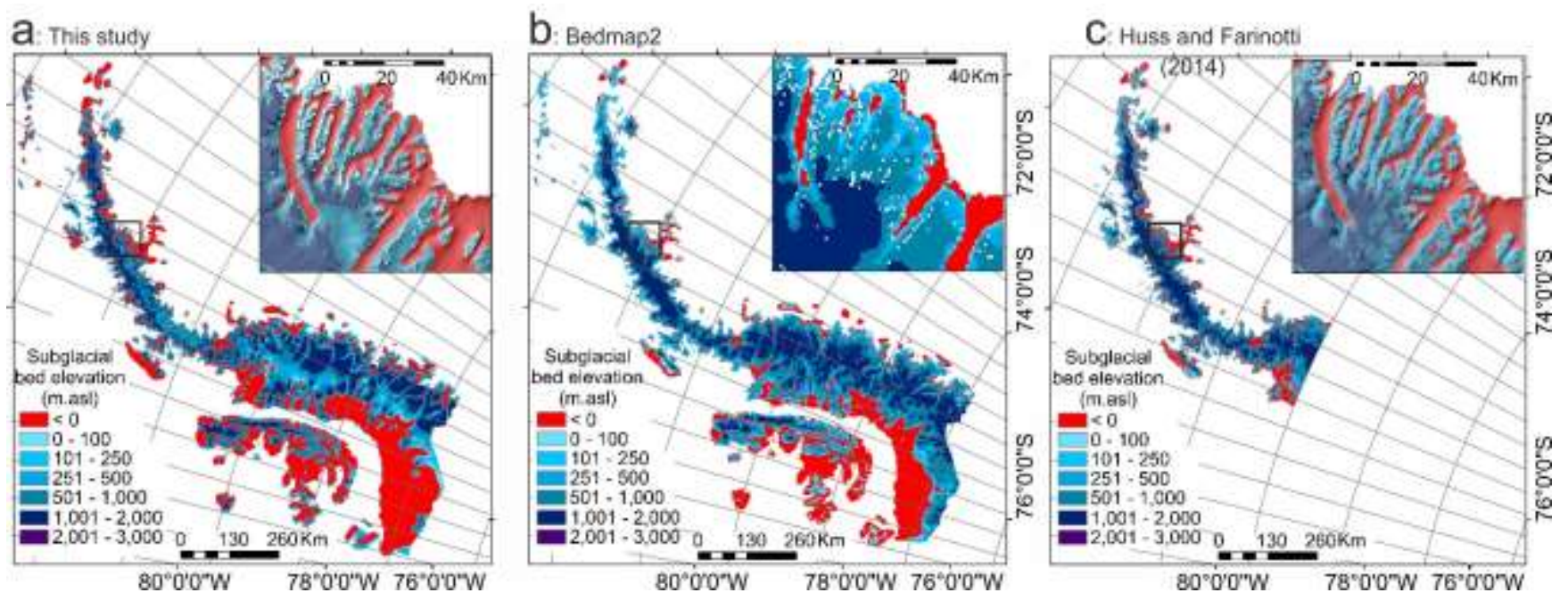

986 Figure 10. Subglacial topography, emphasizing those areas of the Antarctic Peninsula that are below 987

988 sea level and so potentially contribute by a relatively small amount to sea-level rise, as modelled by this 989 study (a) within the Bedmap2 (Fretwell et al., 2013) dataset (b) and as modelled by Huss and Farinotti

990 (2014) (c). Note that the insets in panels $a$ and $b$ are underlain by hillshaded bed topography for clarity 991

992

993

994

995

996

997

998

999

1000

1001 

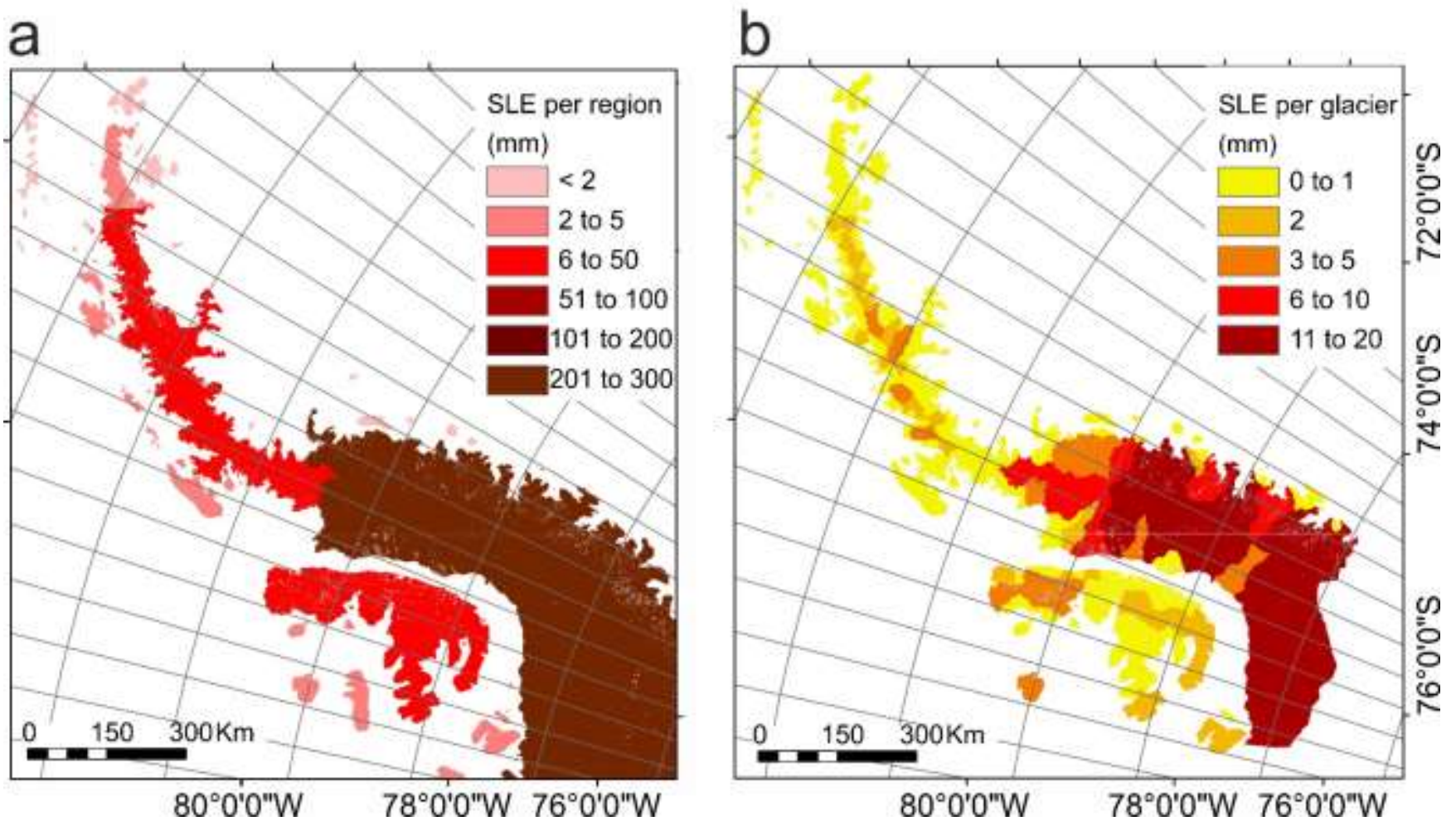

1003 Figure 11. Maximum potential sea-level equivalent (SLE) contributions spatially discriminated per 1004 major region (a) and per glacier (b). Note the colour scales are different between the two panels. 